Use of Wildlife WebcamsLiterature Review and Annotated Bibliography.

By Joan M. Ratz and Shannon J. Conk
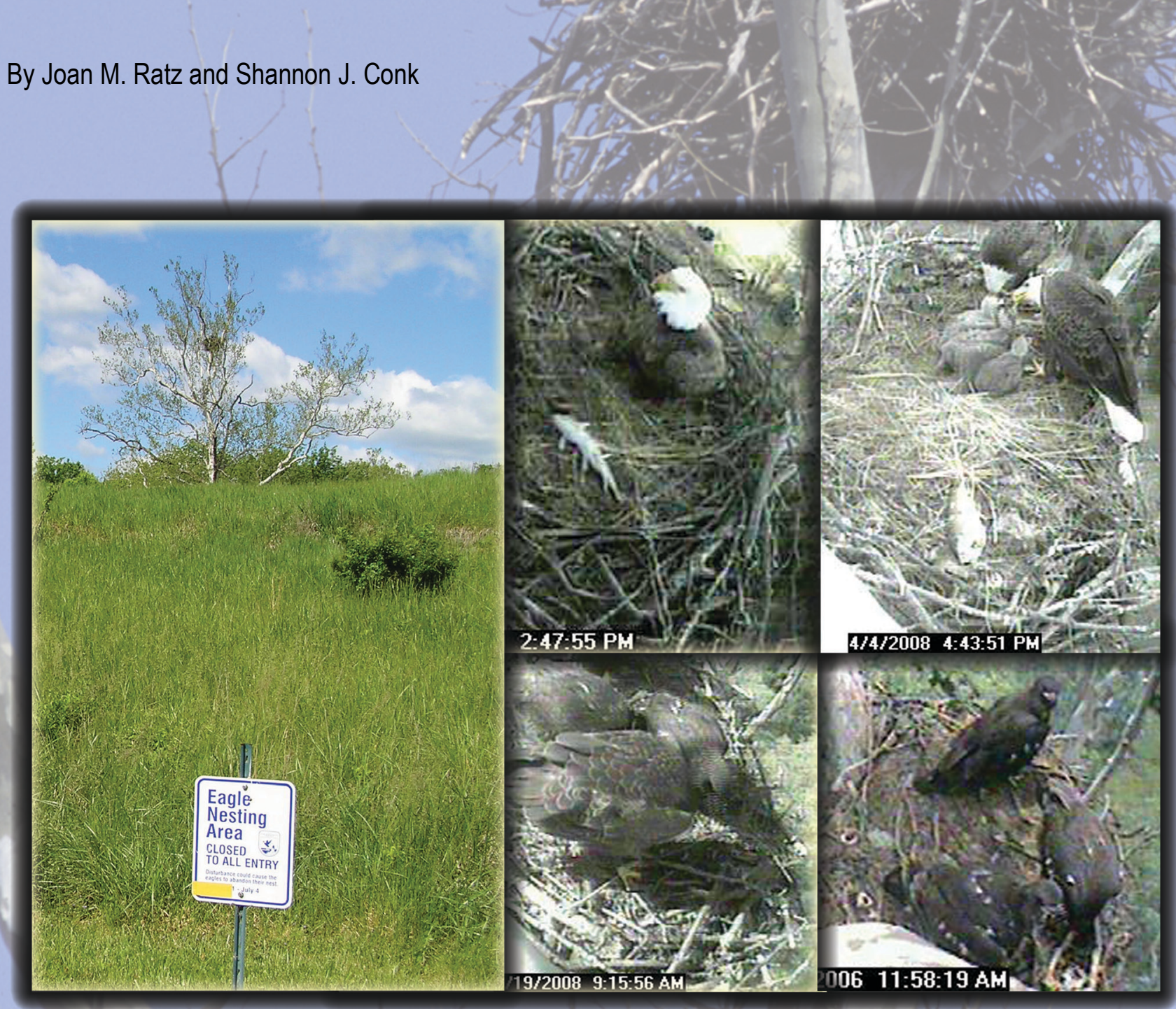

Open-File Report 2010-1306

U.S. Department of the Interior U.S. Geological Survey 


\section{U.S. Department of the Interior \\ KEN SALAZAR, Secretary}

\section{U.S. Geological Survey \\ Marcia K. McNutt, Director}

U.S. Geological Survey, Reston, Virginia 2010

For product and ordering information:

World Wide Web: http://www.usgs.gov/pubprod

Telephone: 1-888-ASK-USGS

For more information on the USGS-the Federal source for science about the Earth, its natural and living resources, natural hazards, and the environment:

World Wide Web: http://www.usgs.gov

Telephone: 1-888-ASK-USGS

Suggested citation:

Ratz, J.M., Conk, S.J., 2010, Use of wildlife webcams-Literature review and annotated bibliography: U.S. Geological Survey Open-File Report 2010-1306, 42 p.

Any use of trade, product, or firm names is for descriptive purposes only and does not imply endorsement by the U.S. Government.

Although this report is in the public domain, permission must be secured from the individual copyright owners to reproduce any copyrighted material contained within this report. 


\section{Contents}

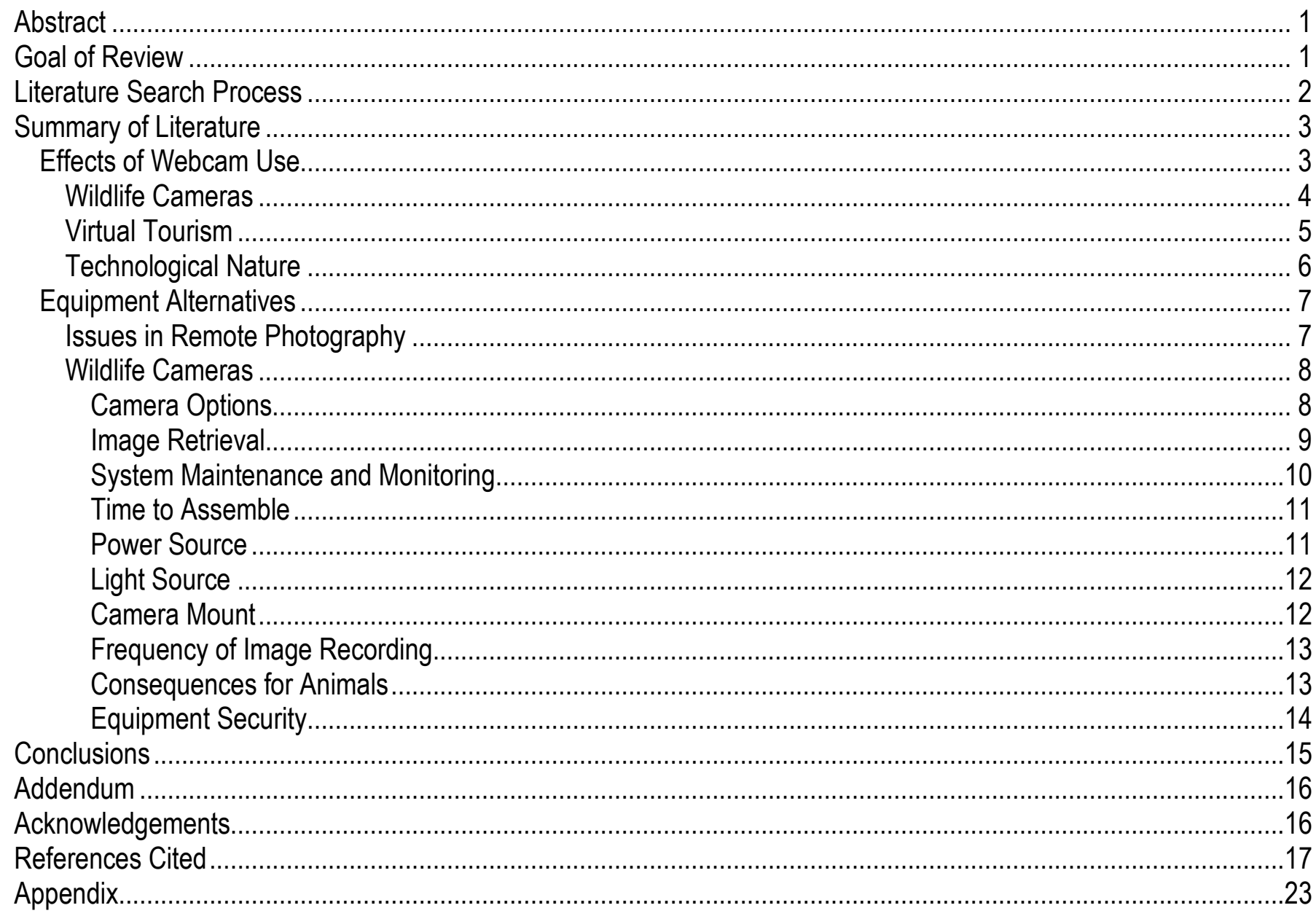

\section{Table}

1. Annotated references and topics addressed in select wildlife remote photography articles 


\title{
Use of Wildlife Webcams: Literature Review and Annotated Bibliography
}

\author{
By Joan M. Ratz and Shannon J. Conk
}

\begin{abstract}
The U.S. Fish and Wildlife Service National Conservation Training Center requested a literature review product that would serve as a resource to natural resource professionals interested in using webcams to connect people with nature. The literature review focused on the effects on the public of viewing wildlife through webcams and on information regarding installation and use of webcams. We searched the peer reviewed, published literature for three topics: wildlife cameras, virtual tourism, and technological nature. Very few publications directly addressed the effect of viewing wildlife webcams. The review of information on installation and use of cameras yielded information about many aspects of the use of remote photography, but not much specifically regarding webcams. Aspects of wildlife camera use covered in the literature review include: camera options, image retrieval, system maintenance and monitoring, time to assemble, power source, light source, camera mount, frequency of image recording, consequences for animals, and equipment security. Webcam technology is relatively new and more publication regarding the use of the technology is needed. Future research should specifically study the effect that viewing wildlife through webcams has on the viewers' conservation attitudes, behaviors, and sense of connectedness to nature.
\end{abstract}

\section{Goal of Review}

The U.S. Fish and Wildlife Service (FWS) National Conservation Training Center (NCTC) hosts a pair of bald eagles on its campus near Shepherdstown, W. Va. The NCTC installed a webcam (referred to as the NCTC Eagle Cam) in such a position that it provides a direct view down into the eagle nest. The NCTC Eagle Cam generates a lot of interest. For example, a "Friends" group - a group of private citizens formed to support a refuge or park - originated from a group of people who viewed the webcam and read a blog about the eagle cam (http://eaglecam.blogspot.com/). The Eaglet Momsters (http://eagletmomsters.com/) are an ad-hoc Friends group that raises funds to support the webcam. They have engaged in activities that indirectly support the eagles. For example, NCTC allows limited deer hunting on the campus to control the deer population. These dedicated viewers of the Eagle webcam heard shots through the microphone on the webcam and noticed that the eagles were disturbed by the sound and left the nest. The situation was reported to NCTC so that action could be taken to minimize disturbance to the eagles (Randy Robinson, oral commun., 2010). Other organizations and agencies with an interest in installing and operating a webcam at their own facilities have contacted the NCTC with questions about the webcam. Staff at the NCTC can provide information about the technical issues of installation of their webcam, but they lack a resource that provides information on the effect of webcams on the viewing public and the range of webcam options available.

The FWS is making an effort to use technology to connect people with nature and to generate interest in the refuges it manages. Podcasts about refuge features and a refuge cellphone tour are among 
the technologies being used to reach the public (Leggett, 2009). There is a need to know in what way and how well these technologies work to connect people with nature and the effect they have on environmental attitudes and behaviors.

The NCTC entered an intragovernmental agreement with the U.S. Geological Survey (USGS) Policy Analysis and Science Assistance Branch (PASA), located at the Fort Collins Science Center (FORT), to produce a literature review and an annotated bibliography summarizing current research and information available on the use of wildlife webcams. The purpose of the literature review was to provide the NCTC with a synthesis of peer reviewed information regarding the positive, indirect effects of webcam viewing by the public. Such a review provides the NCTC with information to support decisions about their own webcam and also allows them to advise other organizations and agencies considering the use of wildlife webcams. Additionally, a summary of equipment alternatives and an annotated bibliography provide tools that the NCTC can distribute to interested parties. The summary and bibliography will help others locate resources describing webcam alternatives including equipment and installation options.

\section{Literature Search Process}

Each author (Ratz and Conk) independently conducted a literature search. We looked for case studies of webcam use with wildlife and for studies that linked webcam use to conservation education outcomes, and conservation interest and behaviors. The initial search, conducted by Conk, involved using the key phrases "wildlife webcam", "wildlife web cam", "nature webcam", and "nature web cam" to search in the EBSCO and LexisNexis publication databases, and in the Google and Google Scholar online search engines. While this search resulted in locating some articles about use of webcams to view wildlife, the articles did not make a connection (beyond anecdotes or speculation) between viewing webcams and the development of a sense of connectedness to the environment or enhanced conservation attitudes. The articles generally described the type of animal viewed and perhaps commented on the number of viewer hits the website had received. The articles located in this search were often from popular rather than scholarly publications. When this initial search yielded less information than we expected, Ratz completed a second literature search. This search involved using the same four key phrases in the Web of Science, Agricola, and Wildlife \& Ecology Studies databases. This second search was as fruitless as the first.

Surprised by this outcome, we enlisted the help of two research librarians: the FORT librarian and a reference librarian at Colorado State University specializing in Natural Resources content areas. We described the intent of our literature search, the key phrases we used, and in which databases or search engines we had searched, and asked for the librarians' assistance in refining or redirecting our search. Based on their recommendations, we conducted new searches in the Web of Science, CAB Abstracts, and Agricola databases. We used the following key phrases as search terms: nest camera*, wireless camera*, video camera*, miniature video camera*, digital camera*, camera station*, and camera*. In the search terms, the asterisks imply the use of a wildcard search. For example, using an asterisk following the "camera" results in the inclusion of all possible endings and would include "camera" and "cameras" in the same search. Each of these seven key phrases was searched twice in each database, once paired with the word "wildlife" and once paired with the word "animal". This search resulted in hundreds of citations; we selected 90 articles to review.

We selected articles based on the recency of the publication, the level of detail in describing the technology, and the contribution to our review. Technology changes rapidly and because of the lag in publication time there were no articles that described state-of-the-art camera technology. In this report, we tried to include articles describing more recent technology rather than outdated technology. For 
some articles, the focus was the camera technology and its suitability for use in wildlife studies. We included as many of these as we could without undue redundancy. We included articles in our revieweven if they were dated - if a technology or use of remote photography was described in the article that was not described elsewhere in the set of articles we reviewed. We consider this set of references to be the result of our "wildlife camera" topic search. Very few of these articles specifically discussed the use of webcams. However, they did provide information on the use of multiple camera technologies that may be of interest to someone considering installation of a webcam.

While reviewing these articles, we came across a reference to virtual tourism. This reference prompted us to conduct another search in the same three databases as the "wildlife camera" search, using the key phrase "virtual tourism". We used four key phrases in this search; we searched with "virtual tourism" alone and paired with the words "animal", "wildlife", and "nature". We located 13 articles to review by this search process. While reviewing the virtual tourism articles, we discovered two additional possible search terms - "virtual nature" and "cybertourism". In the same databases as the other searches, we conducted searches using "virtual nature" and searches using "cybertourism" alone and paired with the words "animal", "wildlife", and "nature". The search results added another five articles to our review.

Finally, Ratz was browsing through a journal and incidentally located an article referring to "technological nature", so we conducted another literature search using "technological nature" as a key phrase. We located one additional article using this search term.

\section{Summary of Literature}

There were two goals for our literature review. We first intended to identify and summarize the effects on people who view wildlife through webcams. Second, we reviewed the literature for information on equipment alternatives and issues necessary for someone installing a webcam to consider. We summarized the literature relevant to each goal separately. Because we reviewed three distinct sets of publications — wildlife cameras, virtual tourism, and technological nature — we grouped our summaries accordingly.

\section{Effects of Webcam Use}

In our literature search, we looked for studies that provided evidence of the effects on the public of viewing wildlife through webcams. Specifically, we were interested in how webcam viewing affected viewers' environmental and conservation attitudes, outdoor recreation behaviors, and sense of connectedness to the environment. Is viewing wildlife webcams linked with an increased interest in environmental concerns? Increased interest in the natural world? Increased participation in outdoor recreation? Is viewing wildlife webcams a substitute activity for outdoor recreation, making people less likely to go outdoors? Does viewing wildlife webcams promote a sense of connectedness to the environment or foster a sense of disconnectedness by making experiencing nature like watching a television show? Or, does viewing wildlife webcams have no effect on attitudes and behaviors? We searched for research studies that addressed these questions.

We were unable to identify any studies that directly addressed these questions for webcams. We subsequently looked to analogous literatures that would still be informative about these questions, albeit not precisely on point. In the wildlife camera literature, we found speculation about how webcams or other forms of remote photography footage could be used to connect with and inform the public. The virtual tourism literature includes survey research on people's opinions of virtual travel, although much of the research is not specific to travel to natural areas. The technological nature literature is newer and 
therefore limited. Early results of this body of research indicate that people can gain benefits from experiencing nature through technology, but that the benefits may be limited. These three literatures are summarized in more detail below.

\section{Wildlife Cameras}

We scanned the literature on a broad range of remote photographic techniques to find information that would be pertinent to those considering using webcams to observe wildlife and to connect people with nature. Studies conducted for many different purposes make use of remote photography. Remote photography is used in studies of wildlife crossing structures (Braden and others, 2008; Donaldson, 2007; Fiehler and others, 2007; Kleist and others, 2007; Ng and others, 2004), wildlife use of water catchments (Lynn and others, 2008; O'Brien and others, 2006), wildlife reaction to fences (Karhu and Anderson, 2006; VerCauteren and others, 2007), wildlife presence and population estimates of species (Foresman and Pearson, 1998; Harrison, 2006; Hristov and others, 2008; Huckschlag, 2008; Kelly and others, 2008; Larrucea and others, 2007; Locke and others, 2005; MacNulty and others, 2008; Marnewick and others, 2008; Moruzzi and others, 2002; Scheibe and others, 2008; Silveira and others, 2003; Song and others, 2008; Srbek-Araujo and Chiarello, 2005; Stewart and others, 1997; Watts and others, 2008; Yasuda and Kawakami, 2002), the effect of human presence and disturbance on animals (DeLap and Knight, 2004; George and Crooks, 2006; Langston and others, 2007; Salgado Kent and Crabtree, 2008), wildlife reproductive behaviors (Langbein and others, 1998; Maniscalco and others, 2006; Newbery and Southwell, 2009), nest studies (Cain and others, 2003; Grivas and others, 2009; Hanula and others, 2000; Hebert and Golightly, 2007; Hudson and Bird, 2006; King and others, 2001; Kristan and others, 1996; Lewis and others, 2004; Malt and Lank, 2007; Margalida and others, 2006; McQuillen and Brewer, 2000; Pietz and Granfors, 2000; Purcell and Verner, 1999; Reif and Tornberg, 2006; Renfrew and Ribic, 2003; Rogers and others, 2005; Staller and others, 2005; Steen, 2009; Sykes and others, 1995; Thompson and Burhans, 2003; Towerton and others, 2008), specific animal behavior (Stevens and Serfass, 2005), and den studies (McGee and others, 2005).

However, we found very few studies that described the potential impact on the public of viewing wildlife through technological means beyond the mere mention of the possibility of using photographs for educational purposes (Cutler and Swann, 1999; Locke and others, 2005; Reif and Tornberg, 2006; Siraj-Blatchford, 2006; Swann and others, 2004). Siraj-Blatchford (2006) suggested that using webcams that were set up to view wild areas could be a way of allowing children to learn from the environment. Kooyman (2007) described the positive effect that the television series "CRITTERCAM Chronicles" has had on public interest in the environment; Moll and others (2007) noted that the same television series has a lot of public appeal and educational value. However, no systematic research on public response to the program was reported. Kristan and others (1996) developed and tested a video camera with a wireless transmitter to record activities in an osprey nest. The footage was available for public viewing at a visitor center near the location of the transmitter. The authors noted the public accessibility of the video and comment that interpretive information was provided by the U.S. Forest Service, but did not describe the public response. Locke and others (2005) posted the photographs collected from their web-based, digital camera system to a website to make the photographs accessible to the public. They briefly discussed the value of having such photographs available to the public and the potential for using photographs as educational tools; however, they did not provide any data on the extent to which the photographs were viewed or how they were used by the public. We found no specific research on the effect on individuals of using webcams or other media to present wildlife footage. 
Protecting the environment may be another outcome of viewing wildlife via webcam. The research of George and Crooks (2006) demonstrated that human activity in natural areas affects wild animal use of the same area. In their literature review, they cited the adverse effect of human recreation in the outdoors on the survival of wildlife. Although George and Crooks (2006) did not make the argument, their research and the literature they cited could be used to support the position that observing wildlife through remote means may be more environmentally friendly than actual observation of wildlife in the outdoors. An example of this potential use is the webcam at the McNeil River State Game Sanctuary in Alaska. The webcam allows more individuals to view the bears ("Current Biology", 2006). Access to the sanctuary is limited and those individuals granted access are selected by lottery. Although we found evidence of webcams being used to expose individuals to wildlife, we could not locate any research articles demonstrating whether individuals' intended or actual recreation in natural areas was affected by viewing wildlife webcams or wildlife footage distributed through other media.

\section{Virtual Tourism}

Much of the literature on virtual tourism or virtual experiences of nature in scholarly journals and trade publications included comments regarding the effects of experiencing nature through technology rather than directly. However, many of those comments were speculative (for example, Caneday, 1992) rather than empirically based. In the articles reporting data-based research, surveys were a common research method. While survey research is a useful method, it does not provide the same perspective as measuring effects after actual exposure to the technology of interest. Finally, there was little in the published literature regarding webcams specifically. Most of the research addressed virtual reality technology. Prideaux (2002, p. 318) defined the term cybertourism as "an electronically simulated travel experience that is a substitute for a physical tourism experience". This definition is more inclusive than virtual tourism and could be interpreted to extend to the use of webcams.

Researchers anticipate that virtual reality or virtual tourism will have an effect on travel to natural places. However, the potential effect is viewed as being either beneficial or detrimental with no consensus as to which is the more likely outcome. Virtual tourism could benefit sensitive natural areas by encouraging individuals to view the area remotely rather than travel there reducing the impact on the environment (Caneday, 1992). Alternatively, virtual tourism could compete with travel to natural areas (Williams and Hobson, 1995), and refuges and recreation areas that rely on visitation fees could suffer if more people chose to visit remotely. Okada and others (2002) described but did not offer an empirical evaluation of a digitally constructed depiction of the natural world in which people can interact to experience nature and discuss environmental issues.

Sussmand and Vanhegan (2000) reported the results of a study on perceptions of virtual tourism. They surveyed two groups — virtual reality researchers and the general British public_-regarding their perceptions of the best and worst aspects of taking a vacation via virtual reality methods and regarding their travel preferences. The results of this study should be treated as tentative due to the small sample size. The findings indicated that people are less favorable to virtual travel than real travel. Both groups identified the best aspect of virtual holidays is the opportunity to experience the destination prior to undertaking travel; both groups identified the worst aspect of virtual holidays as not really experiencing anything. In a slightly more recent publication, Prideaux (2002) reported a similar small sample study to determine the appeal of virtual reality cybertourism among university students. The students perceived cybertourism as an unfavorable substitution for real travel. However, these studies were focused on virtual reality, rather than webcams, and on travel in general, rather than on travel in nature specifically, so it is difficult to determine the degree to which these findings are analogous to the effect of webcams on nature travel or feelings of connection to nature. 
Levi and Kocher (1999) reported the results of three studies examining the outcomes of virtual nature systems. They described virtual nature systems as technology used to experience nature. In the first study, Levi and Kocher used open-ended questions to investigate the attitudes of university students toward the use of virtual reality simulations to experience nature. The results indicated that students were favorable toward using and owning virtual reality systems to experience nature. The second study, in which university students viewed slides of commercial nature photography and local nature photography, demonstrated limited support for the devaluation hypothesis - that experiencing nature through virtual means will cause devaluation of local nature. The third study conducted by Levi and Kocher (1999) addressed the relationship between experiencing nature virtually and attitudes about preservation of national and local parks and natural areas. The authors described several findings from the survey they conducted using a sample of university students; of primary interest is that students reported that their enjoyment of nature, as presented in the form of slides and video, was related to support for preservation of national parks but was not related to support for preservation of local natural areas. The article by Levi and Kocher (1999) was one of few that linked virtual experience of natural areas with attitudes and behaviors. Given that these articles deal with rapidly changing technology and considering the publication dates, the information they contain may be outdated.

In a more contemporary study using a technology closer to webcams than slides and videos, Chambers (2007) investigated the perception of viewing birds using closed-circuit television (CCTV) and the effect on how people viewed their relationship to the birds. The author conducted interviews with volunteers at and visitors to three bird-watching centers in Scotland. The CCTV cameras were viewed as a way to protect the birds as well as a way to raise public awareness of endangered birds and their habitats. Some of the volunteers expressed concern that the CCTV reinforced a tendency in visitors to develop a preference for media-based experiences of nature because they were more likely to see the type of animal activity that they expected via media rather than in actual nature. Interviewees also noted that virtual birding lacks the full sensory experience of birding, which makes it less of a real experience. One interviewee noted that the smell of bird excrement, while not pleasant, is a part of the birding experience. Another interviewee noted that virtual birding may be viewed as "cheating" by real birders because it takes less effort and patience to view birds on a screen than to go out and find them for oneself.

In a rare publication directly addressing webcams, Carpenter and others (2002) argued that wildlife webcams could be used as a source of revenue. They conceded that there was little evidence that wildlife webcams were being used for financial benefit by park managers, but they did describe the webcams as useful public relations and informational tools. However, they cited no evidence in support of that claim. Timothy and Groves (2001) categorized information that can be drawn from webcam imagery and used for research. They focused on webcam imagery used in the tourism industry and noted that "even basic studies on webcams are absent from the tourism literature" (p. 401). It seems there is a general lack of research and publication regarding the use of webcams in general, and specifically regarding the use of webcams for virtual tourism of wild areas.

\section{Technological Nature}

Kahn and others $(2009$, p. 37) used the term technological nature to refer to "technologies that in various ways mediate, augment, or simulate the natural world". They included videos and webcams of natural areas as examples of technological nature. However, the studies they summarized used plasma display screens with nature scenes as the technological nature version of windows. They concluded that people do experience benefits from technological nature in terms of connection to the natural world. 
However, natural windows provided the benefit of recovery from stress as measured by heart-rate and this benefit was not experienced with technological nature.

The design and construction of a classroom incorporating outdoor cameras that transmit imagery to screens inside the building were described in a case study written by the designer and a teacher involved in the design process (Brough and Wigglesworth, 2005). One camera viewed a badger set below the building. A remote-controlled boat with an underwater camera attached to the surface allowed children in the building to view what happened underneath the surface of their pond. The authors expressed that one of the goals in the design of the classrooms and school building was to make the outside world accessible particularly for the children who attend the school and who have disabilities. This article was a case study, not an empirical study, and although the authors described how they addressed the goal of making the outdoors accessible, they did not provide any outcome-based evaluation to demonstrate the effect of this strategy.

We know from the existence of wildlife webcams, such as the NCTC Eagle Cam, that technology can be used to provide people with remote access to wildlife. However, some imagery that could be made available to the public is not. One example of this was described in a study by MacNulty and others (2008). They used a satellite uplink to the internet to transmit streaming video from their study site in Yellowstone National Park to a research center at the University of Minnesota, St. Paul. Although they used the internet to retrieve the imagery, the video footage was restricted to authorized users and could not be accessed by the general public. What we do not know is the effect on attitudes and behaviors of those who view wildlife remotely via technology.

\section{Equipment Alternatives}

Many different aspects of remote photography of wildlife must be considered when using a webcam or other technology to present imagery of wildlife for public outreach or research purposes. First, we summarize several articles that provided good descriptions of remote photography applications. These articles included discussions of: circumstances under which remote photography may be an appropriate choice, necessary components of a video system, and issues to consider when selecting types of equipment. Second, we describe in detail the specific aspects of recording imagery in the wild derived from our review of the wildlife camera literature. Aspects of wildlife camera use covered in the literature review include: camera options, image retrieval, system maintenance and monitoring, time to assemble, power source, light source, camera mount, frequency of image recording, consequences for animals, and equipment security. The literatures we reviewed for virtual tourism and technological nature did not provide information on equipment.

\section{Issues in Remote Photography}

Stewart and others (1997) wrote a review of remote video surveillance of wildlife that is now a bit dated but is otherwise a very detailed review of the components of a remote video system. They described the advantages and disadvantages of remote video surveillance and included descriptions of the processes of setting up a system and processing and archiving the video. The authors described every component of a video system separately: video recorders, cameras, lenses, alarm triggers, monitors, microphones, lights, batteries, power management system, chargers, inverters, alternative power supplies, system housing, and mounts. In addition to providing such a complete description of a video system, they illustrated their points with examples from their video surveillance of badgers. London and others (1998) provided a summary of when to use videography and a detailed description of aspects of the necessary equipment based on their experience in using such equipment in a zoo. McGee 
and others (2005) compared videography of swift fox pups against daytime visual counts and nighttime visual counts using night-vision technology.

In their description of the design of a remote video system intended to detect a specific species, Song and others (2008) explained the four design goals underlying the development of a remote video observation unit. A remote camera or video observation unit should have adequate sensitivity, data reduction capability, accuracy, and robustness. Sensitivity is the ability of the camera and recording system to provide sufficiently high resolution imagery to be able to identify and distinguish the target species from other species. In wildlife videography, many hours of footage that are not of interest can be recorded; the data reduction capability of a system reduces the amount of data recorded, preferably eliminating only footage of low interest. Accuracy is the capability of a camera system to detect and capture footage of the species of interest. Other researchers (see Lyra-Jorge and others, 2008; Malt and Lank, 2007) have addressed the accuracy of different types of triggers (infrared or pressure plate triggers). Triggers need to be sensitive enough to capture the species of interest, but if triggers are too sensitive, pictures will be taken and battery power and storage space are used unnecessarily (Towerton and others, 2008). Robustness is the ability of the system to operate in the environmental conditions (temperature range, humidity) that are characteristic of the study area.

Reif and Tornberg (2006) discussed the technical issues that researchers should consider when choosing video equipment for the remote study of wildlife. They identified the factors affecting choice of video equipment as: the required length of recording sessions, species' sensitivity to disturbance, weather and climate issues, and logistic conditions that include remoteness of study site and skill level of project personnel. Features of the equipment chosen should fit the conditions specified in the study. Important equipment features include type of media on which imagery will be stored, storage capacity of media, system power source, camera light sensitivity, resolution of the imagery, and need for and options for protecting the equipment. They ended their review with a description of their use of a digital video camera to study the diet of goshawks and buzzards.

Huckschlag (2008) described a specific set of requirements for a video system to record animal behavior and the system that was assembled to meet those requirements. A particular concern was that the camera system had to be operational for both day and night recording. The camera selected had two lenses, one suitable for day and one for night.

There are many issues to consider in establishing a camera system to record the behavior of wildlife. Some issues are specific to the intended purpose for establishing the camera system. For example, recording capacity and retrieval may be more important for research studies and less so when the camera system is in place primarily for public access to wildlife. Other issues are specific to the species of interest. Filming animals that are more nocturnal requires cameras that can record at night. The camera system must be mounted and secured in a manner that is appropriate for the environment. Many researchers who have published in the wildlife camera literature discuss these varied issues in detail.

\section{Wildlife Cameras}

\section{Camera Options}

Several types of photographic equipment can be used to record footage or images of wildlife for later distribution. Most of the data gathered, including still photography, can be adapted for distribution on the web. A wide variety of camera options have been described in the literature. Digital cameras were used in studies of wildlife use of safe crossings (Donaldson, 2007), identification of wildlife at a remote site (Yasuda and Kawakami, 2002), and studies of nest predation (Towerton and others, 2008). 
Sykes and others (1995) used a closed-circuit television system with a video recorder to study the incubation, hatching, and fledging of Mississippi Sandhill Cranes. Miniature video cameras were used in some studies of nesting behavior (Lewis and others, 2004; McQuillen and Brewer, 2000) and nest predation (Pietz and Granfors, 2000; Renfrew and Ribic, 2003; Staller and others, 2005; Thompson and Burhans, 2003). Video cameras have been incorporated into animal-borne camera systems (cameras temporarily attached to the animals) to study animal behaviors, including resource use and interactions with other animals (Beringer and others, 2004; Bluff and Rutz, 2008; Heithaus, Dill, and others, 2002; Heithaus, McLash, and others, 2002; Hooker and others, 2002; Rutz and Bluff, 2008). Infrared video camera systems have been used to study animals (Langbein and others, 1998) especially those active in low-light and dark periods (Delaney and others, 1998; Kleist and others, 2007; McGee and others, 2005) or underwater (Chidami and others, 2007). Hristov and others (2008) used thermal infrared imaging to study bats in flight. Some studies cited use of film cameras (Danielson and others, 1996; George and Crooks, 2006; Hanula and others, 2000; Larrucea and others, 2007; Marnewick and others, 2008; Purcell and Verner, 1999; Srbek-Araujo and Chiarello, 2005; York and others, 2001). Smith and others (1993) used a film camera to obtain underwater photographs.

More recent papers described the use of web cameras (Myrick, 2009), digital cameras linked to a web system (Locke and others, 2005), remote controlled video cameras (MacNulty and others, 2008; Maniscalco and others, 2006), and video cameras linked via satellite to the Internet (MacNulty and others, 2008). Myrick (2009) used web cameras in an indoor laboratory for a motion capture study rather than in an outdoor setting to study animals in their natural habitat. MacNulty and others (2008) used robotic video cameras with remote-controlled pan-tilt-zoom features that they could control from the location of their research laboratory at the University of Minnesota, St. Paul.

Hudson and Bird (2006) used a webcam with a portable system to view otherwise inaccessible nests. Unlike the other studies included in this review, this study was unique in that the camera system was moved from nest to nest and was not mounted in place for ongoing recording at one site.

Image Retrieval

Whether the photography is in the form of still photos or video, the photographic imagery must be retrieved from the camera. Current technology allows for image retrieval to be done without actually visiting the camera site. In some cases, the imagery is transmitted to nearby equipment so that the actual recording site will not be disturbed by researchers retrieving the imagery. Contemporary technology allows for data retrieval without having to travel anywhere near the camera site. Yasuda and Kawakami (2002) used a digital PC camera and a streaming server to retrieve their photographic data. King and others (2001) used video cameras with wireless transmitters to send video to a nearby videocassette recorder (VCR). While this allowed for less disturbance around the nests they were studying, the VCR tapes did need to be changed twice per day. Similarly, Song and others (2008) used a wireless transmitter to send video to a nearby computer with an external USB drive for data storage. Until they were able to set up long range wireless transmission, the USB drive had to be changed monthly.

In a study of cliff-dwelling vultures, Margalida and others (2006) used a wireless transmitter to send imagery from cameras mounted on the cliff faces to VCRs connected to receiving transmitters at the study site. Another study of vultures (Grivas, 2009) used a similar design with a video camera mounted in the rock above the nest cavity with a transmission unit, but rather than the storing video on a $\mathrm{VCR}$, the receiving unit was connected to a PC and video was stored on portable hard disks. Kristan and others (1996) used a wireless transmitter to send video recorded at an osprey nest to a nearby visitor center; this arrangement made changing videotapes more convenient and eliminated any disturbance to wildlife caused by VCR maintenance. In a study using underwater video cameras, a transmitter on a 
pontoon sent the video to a receiving unit on shore (Mills and others, 2005). Wireless transmitters were used more frequently with animal-mounted cameras (Beringer and others, 2004).

In some studies (Hebert and Golightly, 2007; Lewis and others, 2004; Pietz and Granfors, 2000; Renfrew and Ribic, 2003; Rogers and others, 2005; Staller and others, 2005) researchers connected cameras to a VCR at the study site using cables. To engage in real-time data transmission, Huckschlag (2009) used cables to connect a very high speed digital subscriber line (VDSL) modem that was part of the camera system to another modem in a laptop. Reif and Tornberg (2006) suggested that commercially available digital video recorders (DVR) designed for use with security surveillance systems are an option for recording in the field. Scheibe and others (2008) compared a VHS recording system to a DVR system. They concluded that the DVR consumed less energy which allowed the system to record longer. Steen (2009) used a mini DVR that stored data on secure digital (SD) cards.

With the latest development in electronic communications, the use of satellite and other relay technology permits imagery retrieval from remote locations. Locke and others (2005) set up the digital camera in their study with a connection to a laptop and satellite phone. The laptop was programmed to connect to the satellite phone twice daily and send pictures to a specified server. Maniscalco and others (2006) used microwave transmission to send imagery from a remote location to the Alaska SeaLife Center where the imagery was recorded onto storage media. The imagery was sent from the cameras to a central control tower near the study site; the central control tower then relayed the transmissions to the Center. MacNulty and others (2008) used a satellite uplink to the internet to transmit imagery; however, the satellite uplink was not completely reliable and required high bandwidth for transmission of data. Based on their experience, they suggested that microwave relay to a dedicated internet connection, rather than a satellite uplink, be used to transmit video. In their review of remote photography technology, Reif and Tornberg (2006) describe global system for mobile (GSM) image submitting cameras which can connect to a mobile phone network to send images. When there is no way to upload the information remotely, the camera sites must be visited to download photos or retrieve video cassettes, hard drives, memory cards, or film for developing; the frequency of maintenance visits varies.

\section{System Maintenance and Monitoring}

Remote photography systems require maintenance to ensure an ongoing source of power, to retrieve the imagery so that more imagery can be recorded, and occasionally to clear snow or debris from the camera lens. The camera systems must be monitored periodically to detect any malfunctions in the system. The maintenance often requires a visit to the camera site. The maintenance/monitoring frequencies reported in the articles we reviewed varied widely. Frequencies were wide ranging with daily (Hanula and others, 2000; Langston and others, 2007; Marnewick and others, 2008; McQuillen and Brewer, 2000; Mills and others, 2005; Pietz and Granfors, 2000; Thompson and Burhans, 2003), every 2-3 days (King and others, 2001; Rogers and others, 2005; Steen, 2009; Stein and others, 2008), once a week (Donaldson, 2007; Larrucea and others, 2007), every two weeks (Grivas and others, 2009; Karhu and Anderson, 2006; O'Brien and others, 2006), and once a month (Song and others, 2008) maintenance reported. Maintenance frequencies seemed tied to the type of technology used. Two of the studies reporting the need for daily maintenance (Hanula and others, 2000; Marnewick and others, 2008) used film cameras to record still photography. Also, studies that used batteries with no solar backup required more frequent maintenance.

In some situations, monitoring during image recording may be necessary. While the CCTV system used by Sykes and others (1995) did not need to be maintained to ensure adequate power, they did monitor the footage as it recorded so that the camera could be adjusted - redirected or zoomed — to capture the best footage available at the time. In another example, the high-speed video recording of the 
courtship behavior of Manakins was monitored by a nearby observer so that the specific behavior of interest would be recorded (Fusani and others, 2007).

\section{Time to Assemble}

The time to assemble and install the components of a remote wildlife camera system varied based upon the type of system being used and characteristics of the camera site. Researchers reported that individual camera systems can be installed in as little as 20 minutes (min) (McQuillen and Brewer, 2000) with an entire set of cameras for a study installed in 1 day (Lyra-Jorge and others, 2008). Lewis and others (2004) reported an average of $75 \mathrm{~min}$ to install miniature video cameras in nests that averaged 14.9 meters in height. Rogers and others (2005) reported a mean set-up time of 110 min per camera. This estimate included the time to view the nest through a TV monitor to ensure proper positioning of the camera. The time to install cameras and transmitters at nests on cliffs averaged 3.4 hours (hr) for Margalida and others (2006) and $4.5 \mathrm{hr}$ for Grivas and others (2009). Delaney and others (1998) calculated the time to assemble the equipment (76 hr) separately from the time to place the cameras (14 hr). Kristan and others (1996) estimate that $60 \mathrm{hr}$ were required for construction and installation of equipment.

The time required to set up a camera system can be lengthy, but comparison to other study methods indicate that use of cameras may be more time efficient. Harrison (2006) determined that the amount of time to set up camera traps was similar to the amount of time required to set up hair-snares or scent stations. In their comparison of camera traps with open and covered track plates, Foresman and Pearson (1998) determined that camera traps required less effort to use than the track plates.

\section{Power Source}

The cameras, as well as the system components to record or transmit the imagery, must have a power source. In one example, the camera was connected to an electrical current through a computer connection cable (Yasuda and Kawakami, 2002). Song and others (2008) report a unique situation that allowed them to tap into a high-voltage power line to supply their system. Sykes and others (1995) used a portable power generator to support their CCTV system and monitoring shed. They used back-up batteries in case of power failure. Most frequently, cameras and other equipment, such as motion sensor triggers, were powered by batteries (Foresman and Pearson, 1998; Huckschlag, 2008; Karhu and Anderson, 2006; King and others, 2001; Locke and others, 2005; McGee and others, 2005; McQuillen and Brewer, 2000; Pietz and Granfors, 2000; Renfrew and Ribic, 2003; Rogers and others, 2005; SrbekAraujo and Chiarello, 2005; Staller and others, 2005; Steen, 2009; Stein and others, 2008; Thompson and Burhans, 2003). Battery failure can compromise the collection and recording of video or photography (Lewis and others, 2004). Lewis and others (2004) maintained continuous operation of their cameras and recording systems by rotating two batteries. To conserve battery power, cameras can be equipped with a light-activated on-off switch (Beringer and others, 2004). In some cases, the batteries were recharged with solar power (Grivas and others, 2009; Kristan and others, 1996; Locke and others, 2005; Lynn and others, 2008; Margalida and others, 2006; Newbery and Southwell, 2009; O'Brien and others, 2006). Solar power was used as an alternate power source for the camera system in some instances ("Current Biology," 2006; Kleist and others, 2007). Margalida and others (2006) used a wind-powered battery charger at one of their study sites. MacNulty and others (2008) and Maniscalco and others (2006) used both solar and wind power to charge their battery systems. 
Light Source

In their discussion of decisions to be made when using videography, London and others (1998) listed supplemental lighting as a key issue. The options they suggested were using no additional light, using infrared light, or using additional non-infrared light. Their discussion focused on the use of infrared lighting; a key issue is to use sufficient light at an appropriate wavelength to permit adequate recording but to limit the infrared light to levels that do not disturb the animals. Underwater photography (Smith and others, 1993) and night-time photography require use of supplemental light sources. Light-emitting diodes (LED) were often used (Chidami and others, 2007; Delaney and others, 1998; Hudson and Bird, 2006; Kleist and others, 2007; Langston and others, 2007; London and others, 1998; Mills and others, 2005; Pietz and Granfors, 2000; Renfrew and Ribic, 2003; Staller and others, 2005). Infrared illuminators have also been used (Huckschlag, 2008; O’Brien and others 2006; Scheibe and others, 2008). To capture the best footage of night behavior, Langbein and others (1998) used infrared spotlights in conjunction with an infrared camera; they used a color camera during the daylight hours.

\section{Camera Mount}

An important consideration in the use of cameras to record and study the behavior of wildlife is the location of the camera. The location of the camera includes the camera site as well as the mount of the camera. The camera must be attached to some type of structure. There is a portion of the research literature using remote photography in which the cameras are mounted to the animals (Adimey and others, 2007; Beringer and others, 2004; Heithaus, Dill, and others, 2002; Heithaus, McLash, and others, 2002; Kooyman, 2007; Moll and others, 2007; Mori and others, 2005; Parrish and Littnan, 2007; Rutz and Bluff, 2008). However, the period of photography is fairly brief for animal-mounted cameras, and this literature is not very relevant to the purpose of this review. Hudson and Bird (2006) provided a detailed description of how they mounted a webcam to a pole and connected the webcam to a laptop in order to view nests. They carried the pole around to view different nests; they did not install a stationary mount for their camera system. Their approach used current technology but in a manner inconsistent with the intent of this review: to provide information for individuals who wish to provide ongoing photo or video coverage of wildlife in a specific setting and make it available to the public. Therefore, we focus our summary on cameras mounted to some feature in the environment.

The cameras must be mounted to a structure that is an existing feature of the physical environment or a structure introduced for the purpose of installing the camera. Use of existing features included mounting the camera to a tree (Danielson and others 1996; Delaney and others, 1998; Donaldson, 2007; Lewis and others, 2004; MacNulty and others, 2008; Malt and Lank, 2007; Rogers and others, 2005; Srbek-Araujo and Chiarello, 2005; Stein and others, 2008; Towerton and others, 2008) or a rock face (Grivas and others, 2009; Margalida and others, 2006). Delaney and others (1998) and Kristan and others (1996) provided detailed descriptions of how they attached video cameras to trees. Some studies used temporary mounts such as camera tripods (Hanula and others, 2000; Scheibe and others, 2008; Sykes and others, 1995); in some cases, mounts were fabricated specifically for the study (Kristan and others, 1996; McGee and others, 2005; McQuillen and Brewer, 2000; O'Brien and others, 2006; Pietz and Granfors, 2000; Renfrew and Ribic, 2003). Newbery and Southwell (2009) altered a surveyor's tripod and secured it with rock mats. Chidami and others (2007) described and diagramed the stainless steel frame they created to mount their infrared video camera for underwater observation. Whenever the camera system operates by use of a sensor to trigger the camera, the mount should be very stable (Huckschlag, 2008; Swann and others, 2004). 


\section{Frequency of Image Recording}

Another consideration when establishing a camera system to record the behavior of wildlife is the frequency with which the camera will operate. Video cameras can be set for continuous recording; video cameras and cameras taking still photos can be programmed on a specific time-lapse schedule or be paired with a sensor to activate only when an animal is in a predetermined range. Cutler and Swann (1999) reviewed published field studies of vertebrates that incorporated either time-lapse or animaltriggered photography, and these authors provided guidance on when each camera timing strategy is most appropriate. In general, setting the camera to a specified time-lapse schedule was preferred when the target animal is frequently in the vicinity of the camera. Animal-triggered photography was preferred when the target animal is in the vicinity of the camera on an infrequent or unpredictable basis. Animal-triggered systems include infrared systems and pressure-plate triggering systems (for examples see Moruzzi and others, 2002; York and others, 2001).

Among the studies we reviewed, infrared triggers were frequently the method of choice for triggering camera systems (Braden and others, 2008; Hanula and others, 2000; Huckschlag, 2008; Marnewick and others, 2008; Srbek-Araujo and Chiarello, 2005; Stevens and Serfass, 2005; Towerton and others, 2008; Watts and others, 2008). Swann and others (2004) compared six infrared-triggered, commercially available wildlife camera systems. They provided recommendations for setting up infrared-triggered systems to maximize camera performance. In a study comparing camera traps with track plotting, Lyra-Jorge and others (2008) determined that the effectiveness of infrared triggers was dependent on animal body mass. They also noted that infrared sensors may not work as well in hot climates in situations where there may not be a sufficient difference between the animal body temperature and environmental temperature to trigger the sensor.

Malt and Lank (2007) found that the time between when the motion detector triggered the camera to initialize and when the camera took the photograph, although it was only four seconds, was too long in some cases and the animal triggering the motion detector departed before being photographed. Scheibe and others (2008) noted that the delay between the camera triggering and the start of recording was problematic. Steen (2009) used a DVR system that had a built in video motion detection (VMD) sensor to trigger recording. Steen concluded that the VMD was sufficiently sensitive to capture images of prey delivery by kestrels and noted that the VMD area could be limited to reduce recording of unwanted activity. Cain and others (2003) described how they connected a trip wire attached to bait eggs to the camera so that when a predator disturbed the eggs the camera was triggered. There are a variety of methods to trigger imagery recording if continuous recording is not an option. To minimize problems caused by the triggering mechanism, the trigger should be matched with the environmental conditions and animal of interest.

Rather than using a trigger, another option is to continuously record within a limited time frame. A webcam at the McNeil River State Game Sanctuary was turned on from 5 a.m. to 11 p.m.; the staff at the Pratt Museum was able to direct the camera for better bear viewing ("Current Biology", 2006). The remote controlled video cameras used by MacNulty and others (2008) were staffed by individuals conducting manual scans periodically between the hours of 7 a.m. and 5 p.m.

\section{Consequences for Animals}

The potential danger posed to the animal of interest when establishing a camera site was one caution to consider mentioned by several authors (Cutler and Swann, 1999; Kristan and others, 1996; McQuillen and Brewer, 2000). Installation of camera equipment near nests can be disruptive to birds, especially when they are nesting or fledging; it is important to be aware of the stage of the nesting cycle and the birds' sensitivity to disruption before installing cameras (Kristan and others, 1996; Margalida 
and others, 2006; Pietz and Granfors, 2000). Cain and others (2003) studied nest predation without disturbing the bird species of interest by using only fledged, depredated, or abandoned nests. The presence of a camera could alert predatory species to a nest or den, or could attract human interest to the site that would be disruptive to the animal. The camera and other equipment were often camouflaged (Grivas and others, 2009; Staller and others, 2005). To prevent attracting predators to the ground nests in their study, Renfrew and Ribic (2003) placed the cameras at or below the height of the nearby vegetation. McQuillen and Brewer (2000) remarked that a camera arm makes a nice perch for predatory birds. Langston and others (2007) painted their equipment to blend in with the landscape and used existing vegetation to cover the equipment. However, as noted by Silveira and others (2003), use of camera technology may create less environmental disturbance than other wildlife observation methods.

\section{Equipment Security}

An additional concern is the security of the camera equipment from environmental conditions (London and others, 1998), animals (Danielson and others, 1996; Grassman and others, 2005; Marnewick and others, 2008), and humans (George and Crooks, 2006; Ng and others, 2004). Concerning environmental conditions, cameras will have different sensitivities to temperature, pressure, and humidity. Newbery and Southwell (2009) tested several models of cameras to determine which would continue to function in the temperature range expected in a polar environment. Weather-proof cases, some of which may also be security cases, were often needed for outdoor cameras and recording equipment. Such cases were commercially available (McQuillen and Brewer, 2000; Newbery and Southwell, 2009; Stewart and others, 1997) or were fashioned by the researchers (Danielson and others, 1996; King and others, 2001; York and others, 2001). York and others (2001) adapted sandwich containers and waterproof food-storage boxes to serve as weatherproof camera boxes. To store their VCRs, Rogers and others (2005) used locked military ammunition cans.

When cameras were used underwater, particularly if the cameras were attached to diving animals, precautions were required to protect the camera and other components against damage caused by water pressure (Hooker and others, 2002). Studies in desert areas used below-ground concrete vaults for components of the recording systems and electronics (Lynn and others, 2008; O'Brien and others, 2006). In climates with greater humidity, researchers often placed silica gel desiccant inside the weatherproof housing for the camera and recording systems to minimize the effect of moisture on equipment function (Lewis and others, 2004; Scheibe and others, 2008; Stewart and others, 1997).

To shield their equipment from the elements and animals, Danielson and others (1996) created protective housing for their cameras with plywood and plexiglass. They found that this design protected camera equipment from weather and most animals, although some of their camera boxes were destroyed by bears. They suggested use of protective boxes fabricated from steel in areas with bear populations. Grassman and others (2005) also recommended use of a metal protective shell for camera equipment in locations where elephants or large carnivores are present or where theft is likely. Marnewick and others (2008) described the commercially available system they used and noted that it continued to work even after being trampled by elephants. To protect their VCR and system battery from cattle, Renfrew and Ribic (2003) fabricated a pyramid-shaped cage from hog fencing. Whenever cables were used to connect components of the camera and recording systems, there was a risk that the cables or wires would be damaged by wildlife (Grivas and others, 2009; Larrucea and others, 2007; Margalida and others, 2006; Reif and Tornberg, 2006; Thompson and Burhans, 2003; York and others, 2001). Options for protecting cables included encasing the cable or burying it (Renfrew and Ribic, 2003). King and others (2001) described in detail how they created weatherproof and camouflage protection for the camera and recording equipment they used to monitor bird nests. By customizing these protective 
covers, they were able to match the protection to the specific equipment they used and the environmental conditions in which they were conducting their study.

Theft of equipment is a concern for researchers conducting remote wildlife photography. In their study of animal use of highway crossings, $\mathrm{Ng}$ and others (2004) used cameras only in areas judged to have low likelihood of theft. Locke and others (2005) included a laptop computer with their equipment that was set up in the field; the laptop was stored in a metal weather-proof container that was sufficiently secure to prevent theft. George and Crooks (2006) encased their cameras in locking steel containers in areas where theft was a risk; they used a cable and lock to secure their cameras in areas where theft was not considered a risk. Fiehler and others (2007) designed a steel security box for mounting and protecting a digital camera. They determined that the security box did not interfere with camera functioning and no cameras were stolen even though there was evidence of human activity around the camera sites.

\section{Conclusions}

In our literature review, we located few studies that addressed the technology of webcams and the effects of their use on viewers' attitudes and perceptions of wildlife and nature. There are several possible reasons for the lack of published literature on webcams. First, the lag time between the submission of a manuscript to a publication outlet and when the published article is available creates an inevitable delay. This is especially true and particularly problematic when the content is a technological topic. Technology changes so rapidly it is impossible for the published research to stay current. It is possible that the current lack of publication on webcams is due to this lag and that articles are coming in the pipeline.

A second possibility is that people are doing research on the use of wildlife webcams but are not publishing their results. Perhaps the studies being completed are small scale or are not otherwise meeting the criteria for publication. If people are collecting data on webcams for their own use and not publishing because they do not perceive the need to publish, they should realize the importance of sharing any information about the use of webcams. This is especially true given the sparseness of the current literature.

Finally, a concerning possibility is that people are not researching nor are they considering researching the effects of wildlife webcams. Rather, they may be using webcams to connect people with the environment based on assumptions that any effects will be positive. Making decisions based on assumptions is problematic, although there are circumstances in which doing so cannot be avoided. Even though it is unlikely that there are no effects of wildlife webcams on viewers' attitudes and behaviors, it is possible that effects are negligible. If that were the case, an investment in a webcam system for the primary purpose of connecting people with nature would be an investment with a low return. Alternately, some effects of viewing wildlife through webcams could be negative. For example, if people are more interested in a webcam at an exotic locale rather than the natural environment in their locality, they may reduce the amount of time they spend outdoors in favor of more time in front of the computer monitor. There is preliminary evidence from the technological nature literature that people can benefit from exposure to technologically mediated nature as experienced through a plasma display screen. It is likely that webcams would have similar positive benefits. However, without fully understanding the characteristics and strength of the effects of viewing wildlife webcams, this technology cannot be fully leveraged for maximum impact on the viewing public. We need a more thorough understanding of the effects.

While environmental education researchers and practitioners can draw on analogous literatures to fill in the gaps in what we know regarding webcams, as we have done here, there is a need for 
research that directly evaluates the effect of viewing wildlife through webcams. Those who are actively engaged in the practice of environmental education need research-based information regarding the effects of using webcams to connect people and nature.

\section{Addendum}

After reviewing an early draft of this report, a representative of the NCTC suggested that we expand our literature search using the key phrases "education" paired with "webcam" and with "web cam". We conducted searches using these key phrases in the EBSCO Academic Premier, LexisNexis, Web of Science, Agricola, and Wildlife \& Ecology Studies databases and in the Google Scholar online search engine. The search of the databases yielded an initial set of 400 references linked to those search terms. We reviewed the titles and abstracts of those 400 references and found that only 14 of them were actually on the topic of webcams and even fewer focused on wildlife. The search of Google Scholar resulted in thousands of initial results. We reviewed the first 100 for each set of search terms and determined that none of the results found with Google Scholar related to our topic of interest.

The relevant articles we found with this supplemental search were primarily from mainstream media sources or trade publications and not scholarly journals. The approach taken in these articles was often descriptive and provided suggestions for how teachers can incorporate use of webcams and other virtual-travel technologies into their classrooms. Some articles described techniques (Maciejewski, 2008; Turner and McLaughlin, 2009) and others provided lists of potentially useful websites and webcams (Dyrli, 2001; Instructor, 2005; Trierweiler, 2005).

Two of the articles described webcams at specific locations. A webcam at Skomer Island, a Welsh wildlife sanctuary, allows viewers the opportunity to watch the wildlife on the island. The island is included as a case study for the National Curriculum, but beyond the number of individuals-students and others - who access the island in person or via the webcam no other information about effects of the webcam was provided in the article (The Western Mail, 2008). In another article, the use of a webcam by a rural school to broadcast images of a set of piglets was described (Shaw, 2006). The popularity of the images provided an opportunity for the school to solicit donations to help support the pigs. The article did not include any description of how viewers were affected by viewing the webcam. In these articles, the claims of educational or other benefits are often assumed or supported with anecdotal rather than empirical evidence. One article that focused on virtual field trips included a comment that an evaluation of a virtual field trip indicated that the virtual experience led to more learning than actual experience, but the article did not provide a reference for that evaluation (Manzo, 2009). None of the articles located in this supplemental search specifically addressed research on how wildlife webcams actually affect those who view them.

\section{Acknowledgements}

This study was requested and funded by the FWS NCTC. We appreciated the opportunity to conduct this review. We are indebted to the reference librarians who assisted us with our literature searches. We would like to thank Megan Eberhardt-Frank, Librarian at the USGS FORT, and Alison Level, Reference Librarian and Associate Professor of Instruction and Research Services at Colorado State University. Two reviewers provided careful and thoughtful critiques of this manuscript. We thank Eric Kelchlin, New Technologies Training Coordinator at the NCTC, and Paul Cryan, Research Biologist at USGS FORT, for their time and efforts to improve this report. 


\section{References Cited}

Adimey, N.M., Abernathy, K., Gaspard, J.C., III, and Marshal, G., 2007, Meeting the manatee challenge-The feasibility of using CRITTERCAM on wild manatees: Marine Technology Society Journal, v. 41, no. 4, p. 14-18.

Current Biology, 2006, Bearing all: Current Biology, v. 16, no. 16, p. R621.

Beringer, J., Millspaugh, J.J., Sartwell, J., and Woeck, R., 2004, Real-time video recording of food selection by captive white-tailed deer: Wildlife Society Bulletin, v. 32, no. 3, p. 648-654.

Bluff, L.A., and Rutz, C., 2008, A quick guide to video-tracking birds: Biology Letters, v. 4, no. 4, p. 319-322.

Braden, A.W., Lopez, R.R., Roberts, C.W., Silvy, N.J., Owen, C.B., and Frank, P.A., 2008, Florida Key deer Odocoileus virginianus clavium underpass use and movements along a highway corridor: Wildlife Biology, v. 14, no. 1, p. 155-163.

Brough, M., and Wigglesworth, S., 2005, A journey in the future-Mossbrook School: Access by Design, no. 104, p. 17-21.

Cain, J.W., Morrison, M.L., and Bombay, H.L., 2003, Predator activity and nest success of willow flycatchers and yellow warblers: Journal of Wildlife Management, v. 67, no. 3, p. 600-610.

Caneday, L., 1992, Outdoor recreation-A virtual reality: Parks and Recreation, v. 27, no. 8, p. 48-52.

Carpenter, J.F., Zatz, D., Mair, J., and Wilkie, D.S., 2002, Virtual tourism: Conservation in Practice, v. 3 , no. 1, p. $37-41$.

Chambers, C.N.L., 2007, "Well its remote, I suppose, innit?” The relational politics of bird-watching through the CCTV lens: Scottish Geographical Journal, v. 123, no. 2, p. 122-134.

Chidami, S., Guenard, G., and Amyot, M., 2007, Underwater infrared video system for behavioral studies in lakes: Limnology and Oceanography-Methods, v. 5, p. 371-378.

Cutler, T.L., and Swann, D.E., 1999, Using remote photography in wildlife ecology-A review: Wildlife Society Bulletin, v. 27, no. 3, p. 571-581.

Danielson, W.R., DeGraaf, R.M., and Fuller, T.K., 1996, An inexpensive compact automatic camera system for wildlife research: Journal of Field Ornithology, v. 67, no. 3, p. 414-421.

Delaney, D.K., Grubb, T.G., and Garcelon, D.K., 1998, An infrared video camera system for monitoring diurnal and nocturnal raptors: Journal of Raptor Research, v. 32, no. 4, p. 290-296.

DeLap, J.H., and Knight, R.L., 2004, Wildlife response to anthropogenic food: Natural Areas Journal, v. 24, no. 2, p. 112-118.

Donaldson, B., 2007, Use of highway underpasses by large mammals and other wildlife in VirginiaFactors influencing their effectiveness: Transportation Research Record, v. 2011, p. 157-164.

Dyrli, O.E., 2001, Live web cams for every content area: Curriculum Administrator, v. 37, no. 1, p. 31. Fiehler, C.M., Cypher, B.L., Bremner-Harrison, S., and Pounds, D., 2007, A theft-resistant adjustable security box for digital cameras: Journal of Wildlife Management, v. 71, no. 6, p. 2077-2080.

Foresman, K.R., and Pearson, D.E., 1998, Comparison of proposed survey procedures for detection of forest carnivores: Journal of Wildlife Management, v. 62, no. 4, p. 1217-1226.

Fusani, L., Giordano, M., Day, L.B., and Schlinger, B.A., 2007, High-speed video analysis reveals individual variability in the courtship displays of male Golden-Collared Manakins: Ethology, v. 113, no. 10, p. 964-972.

George, S.L., and Crooks, K.R., 2006, Recreation and large mammal activity in an urban nature reserve: Biological Conservation, v. 133, no. 1, p. 107-117.

Grassman, L.I., Jr., Tewes, M.E., and Silvy, N.J., 2005, Armoring the Camtrakker ${ }^{\circledR}$ camera-trap in a tropical Asian forest: Wildlife Society Bulletin, v. 33, no. 1, p. 349-352. 
Grivas, C., Xirouchakis, S.M., Christodoulou, C., Carcamo-Aboitiz, B., Georgiakakis, P., and Probonas, M., 2009, An audio-visual nest monitoring system for the study and manipulation of siblicide in bearded vultures Gypaetus barbatus on the island of Crete (Greece): Journal of Ethology, v. 27, p. $105-116$.

Hanula, J.L., Lipscomb, D., Franzreb, K.E., and Loeb, S.C., 2000, Diet of nestling Red-cockaded Woodpeckers at three locations: Journal of Field Ornithology, v. 71, no. 1, p. 126-134.

Harrison, R.L., 2006, A comparison of survey methods for detecting bobcats: Wildlife Society Bulletin, v. 34 , no. 2 , p. $548-552$.

Hebert, P.N., and Golightly, R.T., 2007, Observations of predation by corvids at a Marbled Murrelet nest: Journal of Field Ornithology, v. 78, no. 2, p. 221-224.

Heithaus, M.R., Dill, L.M., Marshall, G.J., and Buhleier, B., 2002, Habitat use and foraging behavior of tiger sharks (Galeocerdo cavier) in a seagrass ecosystem: Marine Biology, v. 140, no. 2, p. 237-248.

Heithaus, M.R., McLash, J.J., Frid, A., Dill, L.M., and Marshall, G.J., 2002, Novel insights into green sea turtle behaviour using animal-borne video cameras: Journal of the Marine Biological Association of the United Kingdom, v. 82, no. 6, p. 1049-1050.

Hooker, S.K., Boyd, I.L., Jessopp, M., Cox, O., Blackwell, J., Boveng, P.L., and Bengston, J.L., 2002, Monitoring the prey-field of marine predators - Combining digital imaging with datalogging tags: Marine Mammal Science, v. 18, no. 3, p. 680-697.

Hristov, N.I., Betke, M., and Kunz, T.H., 2008, Applications of thermal infrared imaging for research in aeroecology: Integrative and Comparative Biology, v. 48, no. 1, p. 50-59.

Huckschlag, D., 2008, Development of a digital infrared video camera system for recording and remote capturing: European Journal of Wildlife Research, v. 54, p. 651-655.

Hudson, M.-A.R., and Bird, D.M., 2006, An affordable computerized camera technique for monitoring bird nests: Wildlife Society Bulletin, v. 34, no. 5, p. 1455-1457.

Instructor, 2005, 5 webcams for kids you don't want to miss: Instructor, v. 115, no. 4, p. 14.

Kahn, P.H., Jr., Severson, R.L., and Ruckert, J.H., 2009, The human relation with nature and technological nature: Current Directions in Psychological Science, v. 18, no. 1, p. 37-42.

Karhu, R.R., and Anderson, S.H., 2006, The effect of high-tensile electric fence designs on big-game and livestock movements: Wildlife Society Bulletin, v. 34, no. 2, p. 293-299.

Kelly, M.J., Noss, A.J., Di Bitetti, M.S., Maffei, L., Arispe, R.L., Paviolo, A., De Angelo, C.D., and Di Blanco, Y.E., 2008, Estimating puma densities from camera trapping across three study sitesBolivia, Argentina, and Belize: Journal of Mammalogy, v. 89, no. 2, p. 408-418.

King, D.I., DeGraaf, R.M., Champlin, P.J., and Champlin, T.B., 2001, A new method for wireless video monitoring of bird nests: Wildlife Society Bulletin, v. 29, no. 1, p. 349-353.

Kleist, A.M., Lancia, R.A., and Doerr, P.D., 2007, Using video surveillance to estimate wildlife use of a highway underpass: Journal of Wildlife Management, v. 71, no. 8, p. 2792-2800.

Kooyman, G., 2007, Animal-borne instrumentation systems and the animals that bear them-Then (1939) and now (2007): Marine Technology Society Journal, v. 41, no. 4, p. 6-8.

Kristan, D.M., Golightly, R.T., and Tomkiewicz, S.M., Jr., 1996, A solar-powered transmitting video camera for monitoring raptor nests: Wildlife Society Bulletin, v. 24, no. 2, p. 284-290.

Langbein, J., Scheibe, K.M., and Eichhorn, K., 1998, Investigations on periparturient behavior in freeranging mouflon sheep (Ovis orientalis musimon): Journal of Zoology, v. 244, no. 4, p. 553-561.

Langston, R.H.W., Liley, D., Murison, G., Woodfield, E., and Clarke, R.T., 2007, What effects do walkers and dogs have on the distribution and productivity of breeding European Nightjar Caprimulgus europaeus?: Ibis, v. 149, supplement 1, p. 27-36. 
Larrucea, E.S., Brussard, P.F., Jaeger, M.M., and Barrett, R.H., 2007, Cameras, coyotes, and the assumptions of equal detectability: Journal of Wildlife Management, v. 71, no. 5, p. 1682-1689.

Leggett, K., 2009, Not your grandparents' tour guide: U.S. Fish and Wildlife Service, Refuge Update, v. 6 , no. 1, p. 14.

Levi, D., and Kocher, S., 1999, Virtual nature-The future effects of information technology on our relationship to nature: Environment and Behavior, v. 31, no. 2, p. 203-226.

Lewis, S.B., DeSimone, P., Titus, K., and Fuller, M.R., 2004, A video surveillance system for monitoring raptor nests in a temperate rainforest environment: Northwest Science, v. 78, no. 1, p. 7074.

Locke, S.L., Cline, M.D., Wetzel, D.L., Pittman, M.T., Brewer, C.E., and Harveson, L.A., 2005, A webbased digital camera for monitoring remote wildlife: Wildlife Society Bulletin, v. 33, no. 2, p. 761765.

London, G.D., Bauman, K.L., and Asa, C.S., 1998, Time-lapse infrared videography for animal behavior observations: Zoo Biology, v. 17, no. 6, p. 535-543.

Lynn, J.C., Rosenstock, S.S., and Chambers, C.L., 2008, Avian use of desert wildlife water developments as determined by remote videography: Western North American Naturalist, v. 68, no. 1, p. 107-112.

Lyra-Jorge, M.C., Ciocheti, G., Pivello, V.R., and Meirelles, S.T., 2008, Comparing methods for sampling large- and medium-sized mammals - Camera traps and track plots: European Journal of Wildlife Research, v. 54, no. 4, p. 739-744.

Maciejewski, J., 2008, 7 quick computer lab activities: Instructor, v. 117, no. 5, p. 62-63.

MacNulty, D.R., Plumb, G.E., and Smith, D.W., 2008, Validation of a new video and telemetry system for remotely monitoring wildlife: Journal of Wildlife Management, v. 72, no. 8, p. 1834-1844.

Malt, J., and Lank, D., 2007, Temporal dynamics of edge effects on nest predation risk for the marbled murrelet: Biological Conservation, v. 140, no. 1-2, p. 160-173.

Maniscalco, J.M., Parker, P., and Atkinson, S., 2006, Interseasonal and interannual measures of maternal care among individual Steller sea lions (Eumetopias jubatus): Journal of Mammalogy, v. 87, no. 2, p. 304-311.

Manzo, K.K., 2009, Virtual field trips open doors for multimedia lessons: Education Week, v. 28 , no. 21, p. 9.

Margalida, A., Ecolan, S., Boudet, J., Bertran, J., Martinez, J.-M., and Heredia, R., 2006, A solarpowered transmitting video camera for monitoring cliff-nesting raptors: Journal of Field Ornithology, v. 77, no. 1, p. 7-12.

Marnewick, K., Funston, P.J., and Karanth, K.U., 2008, Evaluating camera trapping as a method for estimating cheetah abundance in ranching areas: South African Journal of Wildlife Research, v. 38, no. 1, p. 59-65.

McGee, B.K., Butler, M.J., Wallace, M.C., Ballard, W.B., and Nicholson, K.L., 2005, A comparison of survey techniques for swift fox pups: Wildlife Society Bulletin, v. 33, no. 3, p. 1169-1173.

McQuillen, H.L., and Brewer, L.W., 2000, Methodological considerations for monitoring wild bird nests using video technology: Journal of Field Ornithology, v. 71, no. 1, p. 167-172.

Mills, D.J., Verdouw, G., and Frusher, S.D., 2005, Remote multi-camera system for in situ observations of behaviour and predator/prey interactions of marine benthic macrofauna: New Zealand Journal of Marine and Freshwater Research, v. 39, no. 2, p. 347-352.

Moll, R.J., Millspaugh, J.J., Beringer, J., Sartwell, J., and He, Z., 2007, A new 'view' of ecology and conservation through animal-borne video systems: Trends in Ecology and Evolution, v. 22, no. 12, p. 660-668. 
Mori, Y., Watanabe, Y., Mitani, Y., Sato, K., Cameron, M.F., and Naite, Y., 2005, A comparison of prey richness estimates for Weddell seals using diving profiles and image data: Marine Ecology Progress Series, v. 295, p. 257-263.

Moruzzi, T.L., Fuller, T.K., DeGraaf, R.M., Brooks, R.T., and Li, W., 2002, Assessing remotely triggered cameras for surveying carnivore distribution: Wildlife Society Bulletin, v. 30, no. 2, p. 380386.

Myrick, C.A., 2009, A low-cost system for capturing and analyzing the motion of aquatic organisms: Journal of the North American Benthological Society, v. 28, no. 1, p. 101-109.

Newbery, K.B., and Southwell, C., 2009, An automated camera system for remote monitoring in polar environments: Cold Regions Science and Technology, v. 55, no. 1, p. 47-51.

Ng, S.J., Dole, J.W., Sauvajot, R.M., Riley, S.P.D., and Valone, T.J., 2004, Use of highway undercrossings by wildlife in southern California: Biological Conservation, v. 115, no. 3, p. 499-507.

O'Brien, C.S., Waddell, R.B., Rosenstock, S.S., and Rabe, M.J., 2006, Wildlife use of water catchments in southwestern Arizona: Wildlife Society Bulletin, v. 34, no. 2, p. 582-591.

Okada, M., Tarumi, H., Yoshimura, T., Moriya, K., and Sakai, T., 2002, Realization of digital environmental education - A future style of environmental education in dynamically changing virtual environment, in Tanabe, M., van den Besselaar, P., Ishida, T., eds., Digital Cities II-Computational and Sociological Approaches: London, Springer-Verlag, p. 292-304.

Parrish, F.A., and Littnan, C.L., 2007, Changing perspectives in Hawaiian monk seal research using animal-borne imaging: Marine Technology Society Journal, v. 41, no. 4, p. 30-34.

Pietz, P.J., and Granfors, D.A., 2000, Identifying predators and fates of grassland passerine nests using miniature video cameras: Journal of Wildlife Management, v. 64, no. 1, p. 71-87.

Prideaux, B., 2002, The cybertourist, in Dann, G.M.S., ed., The tourist as a metaphor of the social world: Wallingford, England, CABI Publishing, p. 317-339.

Purcell, K.L., and Verner, J., 1999, Nest predators of open and cavity nesting birds in oak woodlands: Wilson Bulletin, v. 111, no. 2, p. 251-256.

Reif, V., and Tornberg, R., 2006, Using time-lapse digital video recording for a nesting study of birds of prey: European Journal of Wildlife Research, v. 52, no. 4, p. 251-258.

Renfrew, R.B., and Ribic, C.A., 2003, Grassland passerine nest predators near pasture edges identified on videotape: Auk, v. 120, no. 2, p. 371-383.

Rogers, A.S., DeStefano, S., and Ingraldi, M.F., 2005, Quantifying Northern Goshawk diets using remote cameras and observations from blinds: Journal of Raptor Research, v. 39, no. 3, p. 303-309.

Rutz, C., and Bluff, L.A., 2008, Animal-borne imaging takes wing, or the dawn of 'wildlife videotracking': Trends in Ecology and Evolution, v. 23, no. 6, p. 292-294.

Salgado Kent, C.P., and Crabtree, B., 2008, The effectiveness of an established sanctuary zone for reducing human disturbance to Australian sea lions (Neophoca cinerea) at Carnac Island, Western Australia: Tourism in Marine Environments, v. 5, no. 1, p. 29-42.

Scheibe, K.M., Eichhorn, K., Wiesmayr, M., Schonert, B., and Krone, O., 2008, Long-term automatic video recording as a tool for analysing the time patterns of utilisation of predefined locations by wild animals: European Journal of Wildlife Research, v. 54, p. 53-59.

Shaw, M., 2006, Cute little piggies find fame online: Leicester, England, Times Educational Supplement, v. 4,681, p. 1.

Silveira, L., Jacomo, A.T.A., and Diniz-Filho, J.A.F., 2003, Camera trap, line transect census and track surveys-A comparative evaluation: Biological Conservation, v. 114, no. 3, p. 351-355. 
Siraj-Blatchford, J., 2006, Emergent science and ICT in the early years, in Warwick, P., Wilson, E., and Winterbottom, M., eds., Teaching and learning primary science with ICT: Berkshire, England, Open University Press, p. 128-147.

Smith, K.L., Jr., Kaufmann, R.S., and Wakefield, W.W., 1993, Mobile megafaunal activity monitored with a time-lapse camera in the abyssal north Pacific: Deep Sea Research Part I-Oceanographic Research Papers, v. 40, no. 11-12, p. 2307-2324.

Song, D., Qin, N., Xu, Y., Kim, C.Y., and Goldberg, K., 2008, System and algorithms for an autonomous observatory assisting the search for the Ivory-Billed Woodpecker, in IEEE Conference on Automation Science and Engineering (CASE), Washington, D.C., August 23-26, 2008, Proceedings: Piscataway, N.J., IEEE Xplore, p. 200-205.

Srbek-Araujo, A.C., and Chiarello, A.G., 2005, Is camera-trapping an efficient method for surveying mammals in neotropical forests? A case study in south-eastern Brazil: Journal of Tropical Ecology, v. 21, no. 1, p. 121-125.

Staller, E.L., Palmer, W.E., Carroll, J.P., Thornton, R.P., and Sisson, C.D., 2005, Identifying predators at northern bobwhite nests: Journal of Wildlife Management, v. 69, no. 1, p. 124-132.

Steen, R., 2009, A portable digital video surveillance system to monitor prey deliveries at raptor nests: Journal of Raptor Research, v. 43, no. 1, p. 69-74.

Stein, A.B., Fuller, T.K., and Marker, L.L., 2008, Opportunistic use of camera traps to assess habitatspecific mammal and bird diversity in northcentral Namibia: Biodiversity and Conservation, v. 17, no. 14, p. 3579-3587.

Stevens, S.S., and Serfass, T.L., 2005, Sliding behavior in Nearctic river otters-Locomotion or play?: Northeastern Naturalist, v. 12, no. 2, p. 241-244.

Stewart, P.D., Ellwood, S.A., and Macdonald, D.W., 1997, Remote video-surveillance of wildlife-An introduction from experience with the European badger Meles meles: Mammal Review, v. 27, no. 4, p. 185-204.

Sussmann, S., and Vanhegan, H., 2000, Virtual reality and the tourism product - Substitution or complement?, in Proceedings of the Eighth European Conference on Information Systems (ECIS), Vienna, Austria, July 3-5, 2000, Proceedings: Vienna, Austria, Wirtschaftsuniversität Wien, p. 10771083.

Swann, D.E., Hass, C.C., Dalton, D.C., and Wolf, S.A., 2004, Infrared-triggered cameras for detecting wildlife-An evaluation and review: Wildlife Society Bulletin, v. 32, no. 2, p. 357-365.

Sykes, P.W., Jr., Ryman, W.E., Kepler, C.B., and Hardy, J.W., 1995, A 24-hour remote surveillance system for terrestrial wildlife studies: Journal of Field Ornithology, v. 66, no. 2, p. 199-211.

The Western Mail, August 27, 2008, Now children can get up close to island's wildlife whatever the weather: The Western Mail, p. 38.

Thompson, F.R., III, and Burhans, D.E., 2003, Predation of songbird nests differs by predator and between field and forest habitats: Journal of Wildlife Management, v. 67, no. 2, p. 408-416.

Timothy, D.J., and Groves, D.L., 2001, Webcam images as potential data sources for tourism research: Tourism Geographies, v. 3, no. 4, p. 394-404.

Towerton, A.L., Penman, T.D., Blake, M.D., Deane, A.T., Kavanagh, R.P., and Dickman, C.R., 2008, The potential for remote cameras to monitor visitation by birds and predators at Malleefowl mounds: Ecological Management \& Restoration, v. 9, no. 1, p. 64-67.

Trierweiler, H., 2005, Web cam magic-Use live cameras to bring the world to your classroom: Instructor, v. 114, no. 5, p. 71.

Turner, W., and McLaughlin, C., 2009, The incredible shrinking earth-Google Earth for today's adventurer: Technology \& Children, v. 13, no. 3, p. 4-5. 
VerCauteren, K.C., Seward, N.W., Lavelle, M.J., Fischer, J.W., and Phillips, G.E., 2007, A fence design for excluding elk without impeding other wildlife: Rangeland Ecology \& Management, v. 60, no. 5, p. 529-532.

Watts, D.E., Parker, I.D., Lopez, R.R., Silvy, N.J., and Davis, D.S., 2008, Distribution and abundance of endangered Florida Key Deer on outer islands: Journal of Wildlife Management, v. 72, no. 2, p. 360366.

Williams, P., and Hobson, J.S.P., 1995, Virtual reality and tourism-Fact or fantasy?: Tourism Management, v. 16, no. 6, p. 423-427.

Yasuda, M., and Kawakami, K., 2002, New method of monitoring remote wildlife via the Internet: Ecological Research, v. 17, p. 119-124.

York, E.C., Moruzzi, T.L., Fuller, T.K., Organ, J.F., Sauvajot, R.M., and DeGraaf, R.M., 2001, Description and evaluation of a remote camera and triggering system to monitor carnivores: Wildlife Society Bulletin, v. 29, no. 4, p. 1228-1237. 


\section{Appendix}

Additional information regarding specific articles that discuss the use of remote photography for research is provided in table 1 . The articles selected for inclusion in the table present detailed information on camera equipment and use. We do not summarize the detailed information provided in each article beyond a brief annotation. In the table, we indicate the topics that are addressed in each article so that individuals can identify articles that will provide the information of most interest to them. The table includes the following information for each article:

- Citation: the complete reference citation.

- Annotation: a summary of the topics regarding remote photography addressed in the article.

- Year: year of publication. Although the year is included in the citation information, we provide it in a separate column because technology is extremely time sensitive.

- Cost of photographic equipment: the cost of photographic equipment cited in the article. If the currency is not noted, the cost is stated in U.S. dollars.

- Set-up time: the time required to set up the camera and recording equipment used in the study.

- Description of set-up process: the actions and processes required to set up the camera and recording and retrieval equipment.

- Maintenance time: the time required to maintain functionality of the camera and recording system. The maintenance time includes time to change batteries, download footage, and conduct other maintenance activities.

- Brand name provided: the brand name of the camera and/or recording equipment used.

- Advantages of camera use: descriptions of the advantages of using a particular camera system or of using a camera system as opposed to other methods.

- Issues with camera use: discussion of aspects of using a camera system that should be considered when using remote photography. This includes many topics but is not a discussion of disadvantages of using wildlife cameras.

- Power source: a description of the power source for the camera and recording equipment. 
Table 1. Annotated references and topics addressed in select wildlife remote photography articles.

\begin{tabular}{|c|c|c|c|c|c|c|c|c|c|c|}
\hline & & & \multicolumn{8}{|c|}{ Topics addressed } \\
\hline Citation & Annotation & ঠ্ঠ & 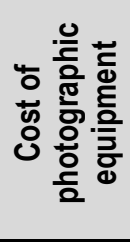 & 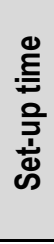 & 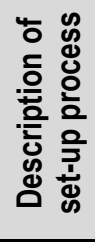 & 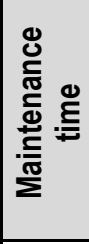 & 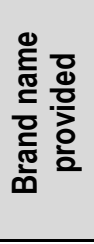 & 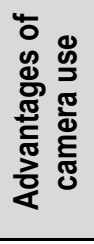 & 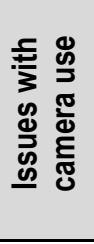 & 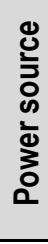 \\
\hline $\begin{array}{l}\text { Newbery, K.B., and } \\
\text { Southwell, C., 2009, An } \\
\text { automated camera system } \\
\text { for remote monitoring in } \\
\text { polar environments: Cold } \\
\text { Regions Science and } \\
\text { Technology, v. 55, no. 1, p. } \\
47-51 .\end{array}$ & $\begin{array}{l}\text { This article is very current and detailed. The authors } \\
\text { describe and discuss each component of the camera system: } \\
\text { digital camera, camera controller, weatherproof case, } \\
\text { external protective shutter, solar panel and battery, tripod, } \\
\text { and rock mat. They describe how they designed a } \\
\text { temporary mount suitable to the harsh environmental } \\
\text { setting. They also describe other issues, such as how } \\
\text { images were stored on a memory card, that demonstrate } \\
\text { how the general process of remote photography was } \\
\text { adapted to an extreme climate and difficult-to-access area. }\end{array}$ & 2009 & & $\mathrm{x}$ & $\mathrm{x}$ & $\mathrm{x}$ & $\mathrm{x}$ & $\mathrm{x}$ & $\mathrm{X}$ & $\mathrm{x}$ \\
\hline $\begin{array}{l}\text { Grivas, C., Xirouchakis, } \\
\text { S.M., Christodoulou, C., } \\
\text { Carcamo-Aboitiz, B., } \\
\text { Georgiakakis, P., and } \\
\text { Probonas, M., 2009, An } \\
\text { audio-visual nest } \\
\text { monitoring system for the } \\
\text { study and manipulation of } \\
\text { siblicide in bearded } \\
\text { vultures Gypaetus barbatus } \\
\text { on the island of Crete } \\
\text { (Greece): Journal of } \\
\text { Ethology, v. 27, p. 105- } \\
116 .\end{array}$ & $\begin{array}{l}\text { These authors used a video camera mounted to rock to } \\
\text { observe nests in rocky cliffs. The camera was battery } \\
\text { powered and linked to a data transmitter. A receiving unit } \\
\text { and recorder in a PC comprised the recording subsystem. } \\
\text { Solar panels were used to recharge and support batteries. } \\
\text { The authors provide a detailed description of the equipment } \\
\text { they used and its installation. They provide comments on } \\
\text { practical issues of camera use. }\end{array}$ & 2009 & $\begin{array}{c}\mathrm{x} \text { (in } \\
\text { Euros) }\end{array}$ & $\mathrm{x}$ & $\mathrm{X}$ & $\mathrm{X}$ & $\mathrm{X}$ & & $\mathrm{X}$ & $\mathrm{X}$ \\
\hline
\end{tabular}




\begin{tabular}{|c|c|c|c|c|c|c|c|c|c|c|}
\hline & & & \multicolumn{8}{|c|}{ Topics addressed } \\
\hline Citation & Annotation & ষ্ঠ & 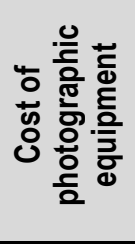 & 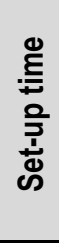 & 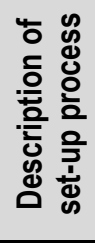 & 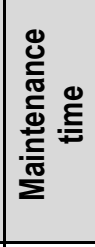 & 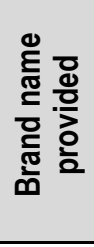 & 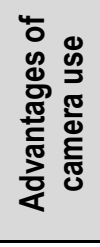 & 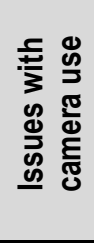 & 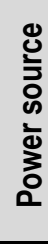 \\
\hline $\begin{array}{l}\text { Steen, R., 2009, A portable } \\
\text { digital video surveillance } \\
\text { system to monitor prey } \\
\text { deliveries at raptor nests: } \\
\text { Journal of Raptor } \\
\text { Research, v. 43, no. 1, p. } \\
\text { 69-74. }\end{array}$ & $\begin{array}{l}\text { This study is one of the most recent included in this review } \\
\text { that used technology more in accordance with the } \\
\text { equipment currently available-a video surveillance system } \\
\text { with a mini DVR. Imagery was stored on a secure digital } \\
\text { (SD) card. The author provides a brief review of } \\
\text { improvements in video technology for wildlife research. }\end{array}$ & 2009 & $\mathrm{x}$ & $\mathrm{x}$ & $\mathrm{x}$ & $\mathrm{x}$ & $\mathrm{x}$ & & $\mathrm{x}$ & $\mathrm{X}$ \\
\hline $\begin{array}{l}\text { Reif, V., and Tornberg, R., } \\
2006, \text { Using time-lapse } \\
\text { digital video recording for } \\
\text { a nesting study of birds of } \\
\text { prey: European Journal of } \\
\text { Wildlife Research, v. } 52 \text {, } \\
\text { no. } 4 \text {, p. } 251-258 .\end{array}$ & $\begin{array}{l}\text { This article focuses on technical issues involved in using } \\
\text { video equipment in wildlife studies. The authors describe } \\
\text { the factors affecting the choice of video equipment (length } \\
\text { of recording sessions, species sensitivity to disturbance, } \\
\text { weather, location remoteness) and the features of the } \\
\text { equipment (capacity of equipment, power source, camera } \\
\text { light sensitivity, image resolution, need for equipment } \\
\text { protection) that must be considered. Additionally, the } \\
\text { authors describe a specific use of a DVR in a study of } \\
\text { goshawk and buzzard diets. }\end{array}$ & 2006 & $\begin{array}{c}\mathrm{x}(\text { in } \\
\text { Euros) }\end{array}$ & $\mathrm{x}$ & $\mathrm{x}$ & & $\mathrm{x}$ & $\mathrm{x}$ & $\mathrm{x}$ & $\mathrm{x}$ \\
\hline $\begin{array}{l}\text { Swann, D.E., Hass, C.C., } \\
\text { Dalton, D.C., and Wolf, } \\
\text { S.A., 2004, Infrared- } \\
\text { triggered cameras for } \\
\text { detecting wildlife-An } \\
\text { evaluation and review: } \\
\text { Wildlife Society Bulletin, } \\
\text { v. } 32 \text {, no. } 2 \text {, p. } 357-365 \text {. }\end{array}$ & $\begin{array}{l}\text { The authors of this study thoroughly compare the } \\
\text { specifications and features of six commercially available } \\
\text { wildlife camera systems. The features compared include the } \\
\text { cost, battery type, battery life, passive versus active infrared } \\
\text { triggers, and sensitivity levels of the cameras. The authors } \\
\text { discuss the advantages and disadvantages of each of the six } \\
\text { camera systems separately. They also recommend strategies } \\
\text { for selecting and mounting infrared-triggered camera } \\
\text { systems for maximum performance. }\end{array}$ & 2004 & $\mathrm{x}$ & & $\mathrm{x}$ & $\mathrm{x}$ & $\mathrm{x}$ & $\mathrm{x}$ & $\mathrm{x}$ & $\mathrm{x}$ \\
\hline
\end{tabular}




\begin{tabular}{|c|c|c|c|c|c|c|c|c|c|c|}
\hline \multirow[b]{2}{*}{ Citation } & \multirow[b]{2}{*}{ Annotation } & \multirow[b]{2}{*}{ ঠ } & \multicolumn{8}{|c|}{ Topics addressed } \\
\hline & & & 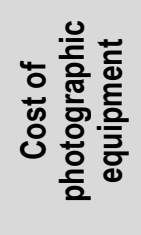 & 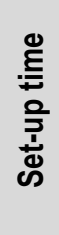 & 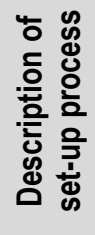 & 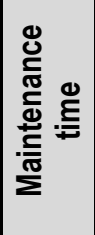 & 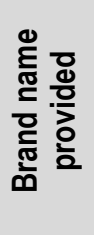 & 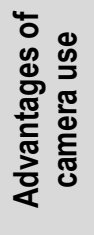 & 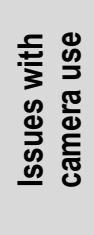 & 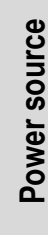 \\
\hline $\begin{array}{l}\text { McQuillen, H.L., and } \\
\text { Brewer, L.W., 2000, } \\
\text { Methodological } \\
\text { considerations for } \\
\text { monitoring wild bird nests } \\
\text { using video technology: } \\
\text { Journal of Field } \\
\text { Ornithology, v. } 71 \text {, no. } 1 \text {, } \\
\text { p. } 167-172 .\end{array}$ & $\begin{array}{l}\text { The purpose of the study described in this article was to test } \\
\text { commercially available video equipment in field } \\
\text { conditions. A miniature video camera and a time-lapse } \\
\text { video recorder were used. The technology described in this } \\
\text { article is now outdated as is the cost information. This } \\
\text { article does provide good descriptions of assembling a } \\
\text { mount for cameras, the amount of time to set up equipment } \\
\text { in the field, and issues with equipment maintenance and } \\
\text { performance. }\end{array}$ & 2000 & $\mathrm{x}$ & $\mathrm{x}$ & $\mathrm{x}$ & $\mathrm{x}$ & $\mathrm{x}$ & & $\mathrm{x}$ & $\mathrm{x}$ \\
\hline $\begin{array}{l}\text { London, G.D., Bauman, } \\
\text { K.L., and Asa, C.S., 1998, } \\
\text { Time-lapse infrared } \\
\text { videography for animal } \\
\text { behavior observations: Zoo } \\
\text { Biology, v. 17, no. 6, p. } \\
\text { 535-543. }\end{array}$ & $\begin{array}{l}\text { The information provided in this article is based on the } \\
\text { authors' experiences in using videography in a zoo. The } \\
\text { authors provide a detailed list of issues to consider when } \\
\text { using videography-whether to videotape, to use real-time } \\
\text { or time-lapse recording, to use additional lighting. They } \\
\text { provide great detail about the equipment necessary to set up } \\
\text { a time-lapse infrared video recording system. They also } \\
\text { emphasize the need to protect camera equipment from } \\
\text { elements of the environment. }\end{array}$ & 1998 & $\mathrm{x}$ & & $\mathrm{x}$ & $\mathrm{x}$ & $\mathrm{x}$ & $\mathrm{x}$ & $\mathrm{x}$ & $\mathrm{x}$ \\
\hline $\begin{array}{l}\text { Stewart, P.D., Ellwood, } \\
\text { S.A., and Macdonald, } \\
\text { D.W., 1997, Remote video- } \\
\text { surveillance of wildlife-- } \\
\text { an introduction from } \\
\text { experience with the } \\
\text { European badger Meles } \\
\text { meles: Mammal Review, v. } \\
\text { 27, no. 4, p. 185-204. }\end{array}$ & $\begin{array}{l}\text { This is a bit dated, but otherwise a very detailed review of } \\
\text { the components of a remote video system and the processes } \\
\text { of setting up a system and processing and archiving the } \\
\text { video. The authors describe every component separately: } \\
\text { video recorders, cameras, lenses, alarm triggers, monitors, } \\
\text { microphones, lights, light switchers, batteries, power } \\
\text { management system, chargers, inverters, alternative power } \\
\text { supplies, system housing, and mounts. They describe the } \\
\text { advantages and disadvantages of remote video surveillance. } \\
\text { While some of the specific equipment they mention may no } \\
\text { longer be available and newer technology is not covered, } \\
\text { this article is a basic reference for anyone considering use } \\
\text { of remote video to record wildlife. }\end{array}$ & 1997 & $\begin{array}{c}\mathrm{x} \text { (in } \\
\text { British } \\
\text { pounds) }\end{array}$ & $\mathrm{x}$ & $\mathrm{x}$ & & $\mathrm{x}$ & $\mathrm{x}$ & $\mathrm{x}$ & $\mathrm{x}$ \\
\hline
\end{tabular}




\begin{tabular}{|c|c|c|c|c|c|c|c|c|c|c|}
\hline & & & \multicolumn{8}{|c|}{ Topics addressed } \\
\hline Citation & Annotation & $\begin{array}{l}\text { ঠ } \\
\text { ঠ }\end{array}$ & 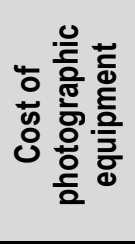 & 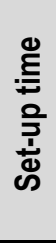 & 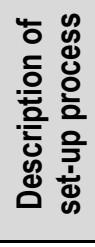 & 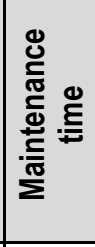 & 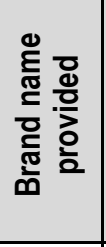 & 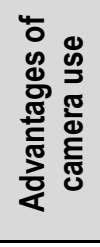 & 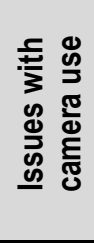 & 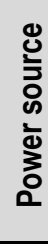 \\
\hline $\begin{array}{l}\text { Lyra-Jorge, M.C., Ciocheti, } \\
\text { G., Pivello, V.R., and } \\
\text { Meirelles, S.T., 2008, } \\
\text { Comparing methods for } \\
\text { sampling large- and } \\
\text { medium-sized mammals- } \\
\text { Camera traps and track } \\
\text { plots: European Journal of } \\
\text { Wildlife Research, v. 54, } \\
\text { no. 4, p. 739-744. }\end{array}$ & $\begin{array}{l}\text { The purpose of the study described in this article was to } \\
\text { compare two methods of detecting and identifying animals: } \\
\text { camera traps and track plotting. Of particular interest in this } \\
\text { report, the authors describe issues with using infrared } \\
\text { sensors to trigger cameras. They suggest that infrared } \\
\text { sensors are not as sensitive in some environments and that } \\
\text { they are more effective for animals with larger body mass. } \\
\text { Animals with lower body mass are not as likely to set off } \\
\text { the sensor and trigger the camera. While these authors do } \\
\text { not provide much detail on the camera equipment, they } \\
\text { provide a succinct discussion of practical strengths and } \\
\text { weaknesses of using cameras to detect wildlife. }\end{array}$ & 2008 & $\mathrm{x}$ & $\mathrm{x}$ & & $\mathrm{x}$ & $\mathrm{x}$ & $\mathrm{x}$ & $\mathrm{x}$ & \\
\hline $\begin{array}{l}\text { Rogers, A.S., DeStefano, } \\
\text { S., and Ingraldi, M.F., } \\
\text { 2005, Quantifying } \\
\text { Northern Goshawk diets } \\
\text { using remote cameras and } \\
\text { observations from blinds: } \\
\text { Journal of Raptor } \\
\text { Research, v. 39, no. 3, p. } \\
\text { 303-309. }\end{array}$ & $\begin{array}{l}\text { This article provides a very detailed description of the } \\
\text { entire process of setting up a remote camera system as well } \\
\text { as a description of the components of the system itself. The } \\
\text { authors describe the required staffing and time to set up the } \\
\text { equipment; they also describe the cost of the equipment } \\
\text { (total and by component), how they mounted the cameras to } \\
\text { trees, how they used a TV monitor to help place the } \\
\text { camera, and how the recording equipment was secured. A } \\
\text { video camera attached to a time-lapse VCR was used. }\end{array}$ & 2005 & $\mathrm{x}$ & $\mathrm{x}$ & $\mathrm{x}$ & $\mathrm{x}$ & $\mathrm{x}$ & & & $\mathrm{x}$ \\
\hline $\begin{array}{l}\text { Srbek-Araujo, A.C., and } \\
\text { Chiarello, A.G., 2005, Is } \\
\text { camera-trapping an } \\
\text { efficient method for } \\
\text { surveying mammals in } \\
\text { neotropical forests? A case } \\
\text { study in south-eastern } \\
\text { Brazil: Journal of Tropical } \\
\text { Ecology, v. 21, no. 1, p. } \\
121-125 .\end{array}$ & $\begin{array}{l}\text { A unique aspect of this study is that the authors used two } \\
\text { brands of cameras and noted different rates of success in } \\
\text { capturing photos of animals between the two brands. The } \\
\text { infrared-triggered cameras took still photos and were } \\
\text { mounted to tree trunks. The authors provide practical } \\
\text { information about using cameras in the field. }\end{array}$ & 2005 & $\mathrm{x}$ & $\mathrm{x}$ & & $\mathrm{X}$ & $\mathrm{X}$ & & $\mathrm{X}$ & $\mathrm{x}$ \\
\hline
\end{tabular}




\begin{tabular}{|c|c|c|c|c|c|c|c|c|c|c|}
\hline \multirow[b]{2}{*}{ Citation } & \multirow[b]{2}{*}{ Annotation } & \multirow[b]{2}{*}{ ঠ } & \multicolumn{8}{|c|}{ Topics addressed } \\
\hline & & & 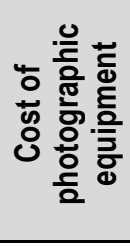 & 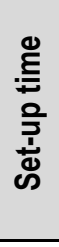 & 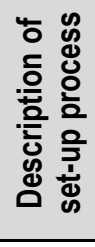 & 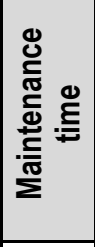 & 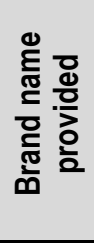 & 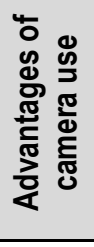 & 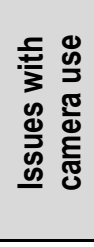 & 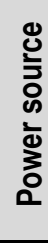 \\
\hline $\begin{array}{l}\text { Lewis, S.B., DeSimone, P., } \\
\text { Titus, K., and Fuller, M.R., } \\
\text { 2004, A video surveillance } \\
\text { system for monitoring } \\
\text { raptor nests in a temperate } \\
\text { rainforest environment: } \\
\text { Northwest Science, v. } 78 \text {, } \\
\text { no. } 1, \text { p. } 70-74 .\end{array}$ & $\begin{array}{l}\text { The authors describe the use of a video surveillance system } \\
\text { to observe nests. The system included a miniature video } \\
\text { camera and a time-lapse VCR. They provide many details } \\
\text { regarding the specifications of the equipment included in } \\
\text { the system and the installation of the equipment, including } \\
\text { the time required for installation. This article is a useful } \\
\text { resource for anyone considering a similar project. }\end{array}$ & 2004 & $\mathrm{x}$ & $\mathrm{x}$ & $\mathrm{x}$ & & $\mathrm{x}$ & & $\mathrm{x}$ & $\mathrm{x}$ \\
\hline $\begin{array}{l}\text { Delaney, D.K., Grubb, } \\
\text { T.G., and Garcelon, D.K., } \\
\text { 1998, An infrared video } \\
\text { camera system for } \\
\text { monitoring diurnal and } \\
\text { nocturnal raptors: Journal } \\
\text { of Raptor Research, v. 32, } \\
\text { no. 4, p. 290-296. }\end{array}$ & $\begin{array}{l}\text { The authors of this article describe in detail the infrared } \\
\text { camera system they used and the manner by which the } \\
\text { cameras were mounted in trees. They also break down the } \\
\text { amount of time required in each phase of the study: } \\
\text { equipment assembly, camera placement, tape and battery } \\
\text { maintenance, and analysis of video tapes. }\end{array}$ & 1998 & $\mathrm{x}$ & $\mathrm{x}$ & $\mathrm{x}$ & $\mathrm{x}$ & $\mathrm{x}$ & & & $\mathrm{x}$ \\
\hline $\begin{array}{l}\text { Foresman, K.R., and } \\
\text { Pearson, D.E., 1998, } \\
\text { Comparison of proposed } \\
\text { survey procedures for } \\
\text { detection of forest } \\
\text { carnivores: Journal of } \\
\text { Wildlife Management, v. } \\
62, \text { no. } 4, \text { p. } 1217-1226 .\end{array}$ & $\begin{array}{l}\text { The camera system described in this article is similar to } \\
\text { those described in many other, more recent articles. The } \\
\text { cameras took still photographs. These authors describe the } \\
\text { issue of camera weight in more detail than other articles } \\
\text { mentioned in this annotated bibliography. }\end{array}$ & 1998 & $\mathrm{x}$ & & & $x$ & $\mathrm{x}$ & $\mathrm{x}$ & $\mathrm{x}$ & $\mathrm{x}$ \\
\hline
\end{tabular}




\begin{tabular}{|c|c|c|c|c|c|c|c|c|c|c|}
\hline \multirow[b]{2}{*}{ Citation } & \multirow[b]{2}{*}{ Annotation } & \multirow[b]{2}{*}{ 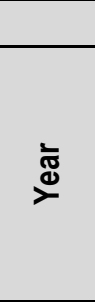 } & \multicolumn{8}{|c|}{ Topics addressed } \\
\hline & & & 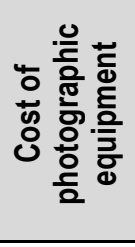 & 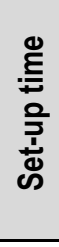 & 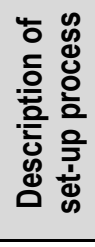 & 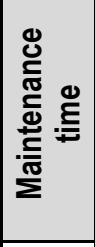 & 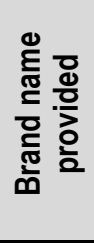 & 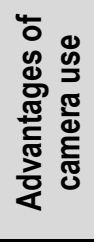 & 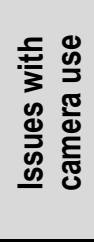 & 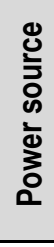 \\
\hline $\begin{array}{l}\text { Song, D., Qin, N., Xu, Y., } \\
\text { Kim, C.Y., and Goldberg, } \\
\text { K., 2008, System and } \\
\text { algorithms for an } \\
\text { autonomous observatory } \\
\text { assisting the search for the } \\
\text { Ivory-Billed Woodpecker, } \\
\text { in IEEE Conference on } \\
\text { Automation Science and } \\
\text { Engineering (CASE), } \\
\text { Washington, D.C., August } \\
\text { 23-26, 2008, Proceedings: } \\
\text { Piscataway, N.J., IEEE } \\
\text { Xplore, p. 200-205. }\end{array}$ & $\begin{array}{l}\text { Song and others provide a lot of detail on issues to consider } \\
\text { in selecting a camera as well as describing four design } \\
\text { goals to consider in compiling a remote photography } \\
\text { system. They provide information on tailoring the camera } \\
\text { setup to record specific species of interest. The technology } \\
\text { used in this study included a video camera networked in to } \\
\text { a computer system. Images were stored on a USB disk that } \\
\text { was changed regularly until a wireless connection was } \\
\text { established. }\end{array}$ & 2008 & & & $\mathrm{x}$ & $\mathrm{x}$ & $\mathrm{x}$ & & $\mathrm{x}$ & $\mathrm{x}$ \\
\hline $\begin{array}{l}\text { Scheibe, K.M., Eichhorn, } \\
\text { K., Wiesmayr, M., } \\
\text { Schonert, B., and Krone, } \\
\text { O., 2008, Long-term } \\
\text { automatic video recording } \\
\text { as a tool for analysing the } \\
\text { time patterns of utilisation } \\
\text { of predefined locations by } \\
\text { wild animals: European } \\
\text { Journal of Wildlife } \\
\text { Research, v. } 54, \text { p. } 53-59 \text {. }\end{array}$ & $\begin{array}{l}\text { As part of their study, these authors compared the use of a } \\
\text { VHS video recording system to a DVR system. They } \\
\text { determined that the DVR provided substantial savings in } \\
\text { energy consumption that allowed for longer recording. }\end{array}$ & 2008 & & & $\mathrm{x}$ & $\mathrm{x}$ & $\mathrm{x}$ & & $\mathrm{x}$ & $\mathrm{x}$ \\
\hline
\end{tabular}




\begin{tabular}{|c|c|c|c|c|c|c|c|c|c|c|}
\hline & & & \multicolumn{8}{|c|}{ Topics addressed } \\
\hline Citation & Annotation & ষ & 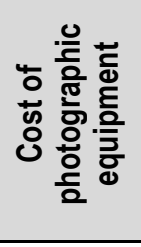 & 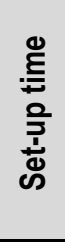 & 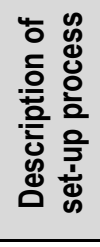 & 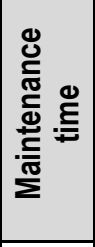 & 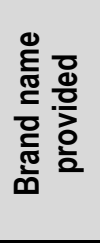 & 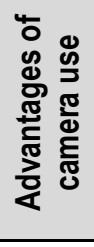 & 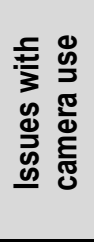 & 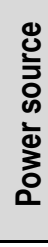 \\
\hline $\begin{array}{l}\text { Huckschlag, D., } 2008 \text {, } \\
\text { Development of a digital } \\
\text { infrared video camera } \\
\text { system for recording and } \\
\text { remote capturing: } \\
\text { European Journal of } \\
\text { Wildlife Research, v. 54, p. } \\
651-655 \text {. }\end{array}$ & $\begin{array}{l}\text { The author used a digital, infrared video camera equipped } \\
\text { with dual lenses for both daytime and nighttime recording. } \\
\text { This video camera was networked to an attached storage } \\
\text { device and a modem. The modem provided the option for } \\
\text { real-time data transmission. A description of issues to } \\
\text { consider in selecting a camera system to meet the needs of } \\
\text { a particular circumstance is provided by the author. This } \\
\text { study is an example of the use of real time data } \\
\text { transmission. Photographs of the equipment are included. }\end{array}$ & 2008 & $\begin{array}{c}\mathrm{x}(\text { in } \\
\text { Euros) }\end{array}$ & & $\mathrm{x}$ & & $\mathrm{x}$ & & $\mathrm{x}$ & $\mathrm{x}$ \\
\hline $\begin{array}{l}\text { Chidami, S., Guenard, G., } \\
\text { and Amyot, M., 2007, } \\
\text { Underwater infrared video } \\
\text { system for behavioral } \\
\text { studies in lakes: Limnology } \\
\text { and Oceanography- } \\
\text { Methods, v. 5, p. } 371-378 \text {. }\end{array}$ & $\begin{array}{l}\text { The study described in this article used a unique setup to } \\
\text { photograph underwater activity. The authors used an } \\
\text { infrared video system with supplemental light-emitting } \\
\text { diodes to observe and record freshwater fish behavior. The } \\
\text { cameras were connected to onshore videotape recorders. } \\
\text { The authors provide a detailed description of how they } \\
\text { assembled the system they used and of the stainless steel } \\
\text { structure they created to mount the camera and lights. }\end{array}$ & 2007 & $\mathrm{x}$ & & $\mathrm{x}$ & $\mathrm{x}$ & $\mathrm{x}$ & & & $\mathrm{x}$ \\
\hline $\begin{array}{l}\text { Hudson, M.-A.R., and } \\
\text { Bird, D.M., 2006, An } \\
\text { affordable computerized } \\
\text { camera technique for } \\
\text { monitoring bird nests: } \\
\text { Wildlife Society Bulletin, } \\
\text { v. } 34 \text {, no. 5, p. } 1455-1457 \text {. }\end{array}$ & $\begin{array}{l}\text { We include this article in the annotated bibliography } \\
\text { because the authors used some of the most current webcam } \\
\text { technology. Most of the articles in this annotated } \\
\text { bibliography focus on the use of a camera in one location. } \\
\text { These authors created a portable system for nest viewing, } \\
\text { and the imagery was recorded on a laptop. The authors } \\
\text { provide detail regarding the specifics of the camera system } \\
\text { they designed and used. }\end{array}$ & 2006 & $x$ & & $\mathrm{x}$ & & $x$ & $\mathrm{x}$ & & $\mathrm{x}$ \\
\hline
\end{tabular}




\begin{tabular}{|c|c|c|c|c|c|c|c|c|c|c|}
\hline \multirow[b]{2}{*}{ Citation } & \multirow[b]{2}{*}{ Annotation } & \multirow[b]{2}{*}{ 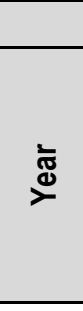 } & \multicolumn{8}{|c|}{ Topics addressed } \\
\hline & & & 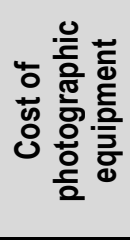 & 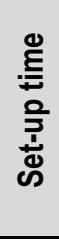 & 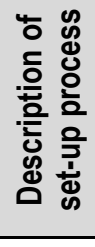 & 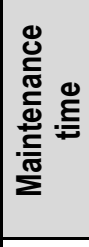 & 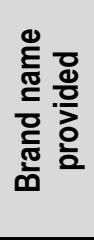 & 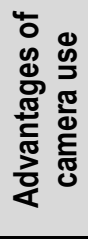 & 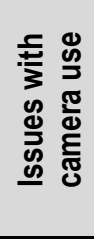 & 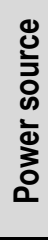 \\
\hline $\begin{array}{l}\text { Renfrew, R.B., and Ribic, } \\
\text { C.A., 2003, Grassland } \\
\text { passerine nest predators } \\
\text { near pasture edges } \\
\text { identified on videotape: } \\
\text { Auk, v. } 120 \text {, no. } 2 \text {, p. } 371- \\
383 \text {. }\end{array}$ & $\begin{array}{l}\text { These authors do not provide a lot of detail about the } \\
\text { camera system they used. However, they do describe } \\
\text { factors to consider in camouflaging and protecting a camera } \\
\text { close to the ground. They describe a pyramid-shaped cage } \\
\text { they built to protect their field VCR from cattle and include } \\
\text { an explanation of why the pyramid shape is not attractive to } \\
\text { cattle. The authors thoroughly describe the potential impact } \\
\text { on birds of camera placement near nests and options for } \\
\text { mitigating those effects. }\end{array}$ & 2003 & & & $\mathrm{x}$ & $\mathrm{x}$ & $\mathrm{x}$ & & $\mathrm{x}$ & $\mathrm{x}$ \\
\hline $\begin{array}{l}\text { Yasuda, M., and } \\
\text { Kawakami, K., 2002, New } \\
\text { method of monitoring } \\
\text { remote wildlife via the } \\
\text { Internet: Ecological } \\
\text { Research, v. 17, p. 119- } \\
124 .\end{array}$ & $\begin{array}{l}\text { Yasuda and Kawakami used a PC camera and a streaming } \\
\text { server to transmit photographic images over distances. } \\
\text { They describe in detail the computer equipment and the } \\
\text { computer and server system requirements. Cost information } \\
\text { is also provided, but amounts are given in Japanese yen. }\end{array}$ & 2002 & $\begin{array}{l}x \text { (in } \\
\text { yen) }\end{array}$ & & $\mathrm{x}$ & & $\mathrm{x}$ & $\mathrm{x}$ & & $\mathrm{x}$ \\
\hline $\begin{array}{l}\text { King, D.I., DeGraaf, R.M., } \\
\text { Champlin, P.J., and } \\
\text { Champlin, T.B., 2001, A } \\
\text { new method for wireless } \\
\text { video monitoring of bird } \\
\text { nests: Wildlife Society } \\
\text { Bulletin, v. 29, no. 1, p. } \\
\text { 349-353. }\end{array}$ & $\begin{array}{l}\text { The focus of this article is on use of video cameras to } \\
\text { monitor a nest. The authors discuss in detail two key topics } \\
\text { that are rarely covered in other articles describing use of } \\
\text { remote photography. First, they describe the use of wireless } \\
\text { transmitters to send the photographic data to a VCR. While } \\
\text { this may now be outdated technology, at the time the article } \\
\text { was published, this was a great innovation, as most studies } \\
\text { used cables to connect the camera to the recording device. } \\
\text { Second, the authors provide a detailed account of how they } \\
\text { constructed the weatherproof and camouflaged containers } \\
\text { for their equipment. }\end{array}$ & 2001 & $\mathrm{x}$ & & $\mathrm{X}$ & $\mathrm{X}$ & $\mathrm{x}$ & & & $\mathrm{X}$ \\
\hline
\end{tabular}




\begin{tabular}{|c|c|c|c|c|c|c|c|c|c|c|}
\hline & & & \multicolumn{8}{|c|}{ Topics addressed } \\
\hline Citation & Annotation & ঠ் & 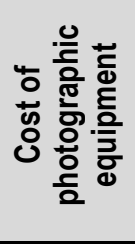 & 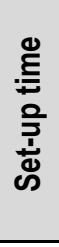 & 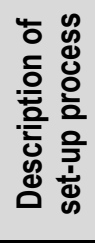 & 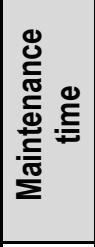 & 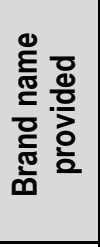 & 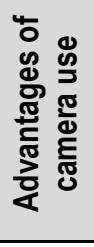 & 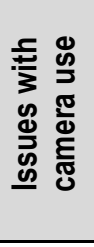 & 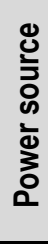 \\
\hline $\begin{array}{l}\text { Kristan, D.M., Golightly, } \\
\text { R.T., and Tomkiewicz, } \\
\text { S.M., Jr., 1996, A solar- } \\
\text { powered transmitting video } \\
\text { camera for monitoring } \\
\text { raptor nests: Wildlife } \\
\text { Society Bulletin, v. 24, no. } \\
\text { 2, p. 284-290. }\end{array}$ & $\begin{array}{l}\text { This article provides great detail in its description of the } \\
\text { video camera and wireless transmission system and is a } \\
\text { great resource for anyone considering a similar } \\
\text { arrangement. The authors describe how they built an } \\
\text { extendable frame to mount the camera to a tree (necessary } \\
\text { because there were no branches over the nest). The system } \\
\text { was powered by battery with a solar recharging system. The } \\
\text { solar panel is described in detail. Video from the osprey } \\
\text { nest was presented on CCTV at a visitor center. }\end{array}$ & 1996 & $\mathrm{x}$ & $\mathrm{x}$ & $\mathrm{x}$ & & & & $\mathrm{x}$ & $\mathrm{x}$ \\
\hline $\begin{array}{l}\text { Sykes, P.W., Jr., Ryman, } \\
\text { W.E., Kepler, C.B., and } \\
\text { Hardy, J.W., 1995, A 24- } \\
\text { hour remote surveillance } \\
\text { system for terrestrial } \\
\text { wildlife studies: Journal of } \\
\text { Field Ornithology, v. 66, } \\
\text { no. 2, p. 199-211. }\end{array}$ & $\begin{array}{l}\text { While this article is dated and the technology may be } \\
\text { obsolete, the authors provide a detailed description of the } \\
\text { setup of a closed-circuit television system with the ability } \\
\text { to adjust the camera as the footage is being recorded. The } \\
\text { system as described does require monitoring by an } \\
\text { individual to make appropriate camera adjustments. The } \\
\text { authors of this study used a portable power generator-a } \\
\text { technique not common in studies using remote } \\
\text { photography. }\end{array}$ & 1995 & $\mathrm{x}$ & & & $\mathrm{x}$ & $\mathrm{x}$ & $\mathrm{x}$ & & $\mathrm{x}$ \\
\hline $\begin{array}{l}\text { Myrick, C.A., } 2009, \text { A } \\
\text { low-cost system for } \\
\text { capturing and analyzing the } \\
\text { motion of aquatic } \\
\text { organisms: Journal of the } \\
\text { North American } \\
\text { Benthological Society, v. } \\
28, \text { no. } 1, \text { p. } 101-109 .\end{array}$ & $\begin{array}{l}\text { Myrick describes the setup and use of web cameras to } \\
\text { conduct a motion study in a laboratory setting. While this } \\
\text { use of web cameras may not be directly applicable to } \\
\text { outdoor use of cameras to record wildlife activity, this } \\
\text { article provides the most up-to-date information regarding } \\
\text { camera cost and availability. }\end{array}$ & 2009 & $\mathrm{x}$ & & $\mathrm{x}$ & & $\mathrm{x}$ & & & $\mathrm{x}$ \\
\hline $\begin{array}{l}\text { Bluff, L.A., and Rutz, C., } \\
\text { 2008, A quick guide to } \\
\text { video-tracking birds, } \\
\text { Biology Letters, v. } 4 \text {, no. } 4 \text {, } \\
\text { p. } 319-322 \text {. }\end{array}$ & $\begin{array}{l}\text { This brief article and the electronic supplementary material } \\
\text { provide extensive detail on the use of animal-borne video } \\
\text { cameras with birds. The article includes a discussion of } \\
\text { ethical and practical considerations in using such an } \\
\text { approach with birds. }\end{array}$ & 2008 & & & $\mathrm{x}$ & & & $x$ & $x$ & $\mathrm{x}$ \\
\hline
\end{tabular}




\begin{tabular}{|c|c|c|c|c|c|c|c|c|c|c|}
\hline \multirow[b]{2}{*}{ Citation } & \multirow[b]{2}{*}{ Annotation } & \multirow[b]{2}{*}{ 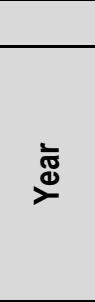 } & \multicolumn{8}{|c|}{ Topics addressed } \\
\hline & & & 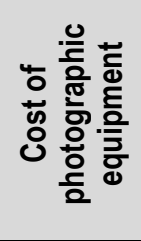 & 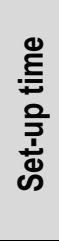 & 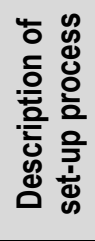 & 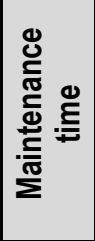 & 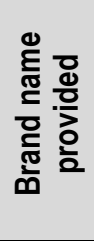 & 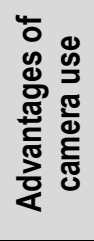 & 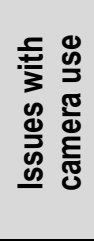 & 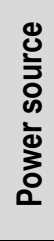 \\
\hline $\begin{array}{l}\text { Towerton, A.L., Penman, } \\
\text { T.D., Blake, M.D., Deane, } \\
\text { A.T., Kavanagh, R.P., and } \\
\text { Dickman, C.R., 2008, The } \\
\text { potential for remote } \\
\text { cameras to monitor } \\
\text { visitation by birds and } \\
\text { predators at Malleefowl } \\
\text { mounds: Ecological } \\
\text { Management \& } \\
\text { Restoration, v. 9, no. 1, p. } \\
64-67 .\end{array}$ & $\begin{array}{l}\text { These authors took still photos with an infrared-triggered } \\
\text { digital camera as part of their wildlife study. This article } \\
\text { does not contain as much description of the camera, } \\
\text { recording system, and installation process as other articles, } \\
\text { although it does include specifics on the camera used. The } \\
\text { technology described in this article may be among the most } \\
\text { recent. }\end{array}$ & 2008 & $\begin{array}{c}\text { x (in } \\
\text { Australi } \\
\text { an } \\
\text { dollars) }\end{array}$ & & $\mathrm{x}$ & $\mathrm{X}$ & $\mathrm{x}$ & & & \\
\hline $\begin{array}{l}\text { MacNulty, D.R., Plumb, } \\
\text { G.E., and Smith, D.W., } \\
2008 \text {, Validation of a new } \\
\text { video and telemetry system } \\
\text { for remotely monitoring } \\
\text { wildlife: Journal of } \\
\text { Wildlife Management, v. } \\
72, \text { no. } 8 \text {, p. } 1834-1844 .\end{array}$ & $\begin{array}{l}\text { Reporting one of the most current studies included in this } \\
\text { review, this article describes the use of a laptop and satellite } \\
\text { phone to transmit video imagery captured at the study site } \\
\text { to a server in a different state that could be accessed by the } \\
\text { researchers. The authors recommend, based on their } \\
\text { experience, that a microwave relay to a dedicated internet } \\
\text { connection may be superior to a satellite uplink. The } \\
\text { cameras used in this study were robotic with remote- } \\
\text { controlled, pan-tilt-zoom function. Cameras were also } \\
\text { equipped with a windshield-wiper function to clear the lens } \\
\text { in bad weather. This is also one of the few studies that used } \\
\text { cameras powered by batteries recharged with wind and } \\
\text { solar panels. }\end{array}$ & 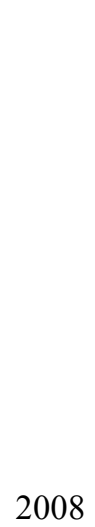 & & & $\mathrm{x}$ & & $\mathrm{X}$ & & $\mathrm{X}$ & $\mathrm{X}$ \\
\hline
\end{tabular}




\begin{tabular}{|c|c|c|c|c|c|c|c|c|c|c|}
\hline & & & \multicolumn{8}{|c|}{ Topics addressed } \\
\hline Citation & Annotation & ঠ্ঠ & 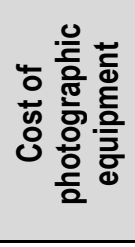 & 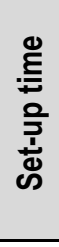 & 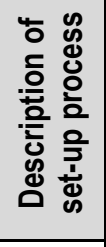 & 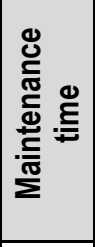 & 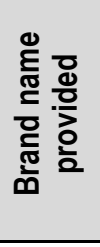 & 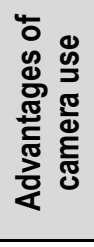 & 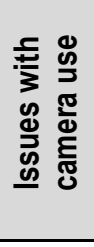 & 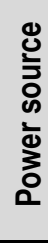 \\
\hline $\begin{array}{l}\text { Fiehler, C.M., Cypher, } \\
\text { B.L., Bremner-Harrison, } \\
\text { S., and Pounds, D., 2007, } \\
\text { A theft-resistant adjustable } \\
\text { security box for digital } \\
\text { cameras: Journal of } \\
\text { Wildlife Management, v. } \\
71, \text { no. 6, p. 2077-2080. }\end{array}$ & $\begin{array}{l}\text { The focus of this article is the construction of a security box } \\
\text { to protect cameras used to study wildlife use of a highway } \\
\text { underpass. The cameras used were digital and took still } \\
\text { photos. Highway underpasses are used by humans as well, } \\
\text { which presents a theft concern for researchers using } \\
\text { cameras. The authors provide a detailed description and a } \\
\text { schematic of the security box. A cost estimate is included. }\end{array}$ & 2007 & $\mathrm{x}$ & & $\mathrm{x}$ & & $\mathrm{x}$ & & & $\mathrm{x}$ \\
\hline $\begin{array}{l}\text { Langston, R.H.W., Liley, } \\
\text { D., Murison, G., } \\
\text { Woodfield, E., and Clarke, } \\
\text { R.T., 2007, What effects do } \\
\text { walkers and dogs have on } \\
\text { the distribution and } \\
\text { productivity of breeding } \\
\text { European Nightjar } \\
\text { Caprimulgus europaeus?: } \\
\text { Ibis, v. 149, supplement 1, } \\
\text { p. 27-36. }\end{array}$ & $\begin{array}{l}\text { In this recent report of remote videography to study birds, } \\
\text { the description of the camera system is somewhat limited. } \\
\text { A one-paragraph appendix to the article provides the } \\
\text { specifics of the camera and time-lapse video recording } \\
\text { equipment. }\end{array}$ & 2007 & & $\mathrm{x}$ & & $\mathrm{x}$ & $\mathrm{x}$ & & & $\mathrm{x}$ \\
\hline $\begin{array}{l}\text { Margalida, A., Ecolan, S., } \\
\text { Boudet, J., Bertran, J., } \\
\text { Martinez, J.-M., and } \\
\text { Heredia, R., 2006, A solar- } \\
\text { powered transmitting } \\
\text { video-camera for } \\
\text { monitoring cliff-nesting } \\
\text { raptors: Journal of Field } \\
\text { Ornithology, v. 77, no. 1, } \\
\text { p. 7-12. }\end{array}$ & $\begin{array}{l}\text { In contrast to many other nesting studies, this study } \\
\text { involved mounting cameras on to a rock face rather than to } \\
\text { a tree. The authors provide details regarding the video } \\
\text { camera and recording system and the wireless transmission } \\
\text { system they used to study cliff-nesting birds. Another } \\
\text { innovation in this study is the use of a wind-powered } \\
\text { battery charger in addition to solar-powered battery } \\
\text { chargers. }\end{array}$ & 2006 & & $\mathrm{X}$ & $\mathrm{x}$ & & $\mathrm{X}$ & & & $\mathrm{x}$ \\
\hline
\end{tabular}




\begin{tabular}{|c|c|c|c|c|c|c|c|c|c|c|}
\hline & & & \multicolumn{8}{|c|}{ Topics addressed } \\
\hline Citation & Annotation & 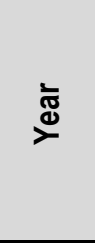 & 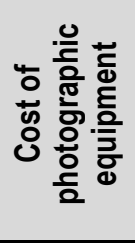 & 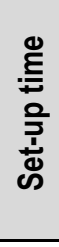 & 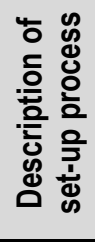 & 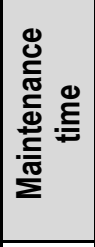 & 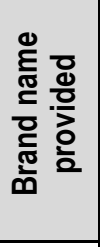 & 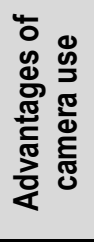 & 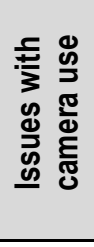 & 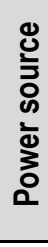 \\
\hline $\begin{array}{l}\text { O'Brien, C.S., Waddell, } \\
\text { R.B., Rosenstock, S.S., and } \\
\text { Rabe, M.J., 2006, Wildlife } \\
\text { use of water catchments in } \\
\text { southwestern Arizona: } \\
\text { Wildlife Society Bulletin, } \\
\text { v. } 34, \text { no. 2, p. 582-591. }\end{array}$ & $\begin{array}{l}\text { The study described in this article is one example of the use } \\
\text { of remote videography in a desert landscape. Although it } \\
\text { doesn't provide a lot of detail about the installation of the } \\
\text { camera system, it does provide more detail than some other } \\
\text { desert studies regarding the use of an underground vault to } \\
\text { house the recording system and other electronic } \\
\text { components. The researchers used a battery system with } \\
\text { solar recharge to power their equipment. }\end{array}$ & 2006 & & & $\mathrm{x}$ & $\mathrm{x}$ & $\mathrm{x}$ & & & $\mathrm{x}$ \\
\hline $\begin{array}{l}\text { McGee, B.K., Butler, M.J., } \\
\text { Wallace, M.C., Ballard, } \\
\text { W.B., and Nicholson, K.L., } \\
\text { 2005, A comparison of } \\
\text { survey techniques for swift } \\
\text { fox pups: Wildlife Society } \\
\text { Bulletin, v. 33, no. 3, p. } \\
\text { 1169-1173. }\end{array}$ & $\begin{array}{l}\text { This article includes a description of the use of a den-probe } \\
\text { cam; this technology was not widely referenced in the other } \\
\text { articles reviewed. While the technology did not work well } \\
\text { for the authors' purposes, they do provide a description of } \\
\text { the equipment that is useful to others who may be } \\
\text { considering that particular technology. The authors also } \\
\text { describe a mounted video camera system they used near } \\
\text { dens to record fox activity. }\end{array}$ & 2005 & $\mathrm{x}$ & & $\mathrm{x}$ & & $\mathrm{x}$ & & & $\mathrm{x}$ \\
\hline $\begin{array}{l}\text { Mills, D.J., Verdouw, G., } \\
\text { and Frusher, S.D., 2005, } \\
\text { Remote multi-camera } \\
\text { system for in situ } \\
\text { observations of behaviour } \\
\text { and predator/prey } \\
\text { interactions of marine } \\
\text { benthic macrofauna: New } \\
\text { Zealand Journal of Marine } \\
\text { and Freshwater Research, } \\
\text { v. 39, no. 2, p. 347-352. }\end{array}$ & $\begin{array}{l}\text { This is one of the few studies to use videography in an } \\
\text { underwater setting. The authors provide specific } \\
\text { information about the components of their system and how } \\
\text { the video data is transmitted from the pontoon to the } \\
\text { receiving unit on shore. }\end{array}$ & 2005 & & & $\mathrm{x}$ & $\mathrm{X}$ & $x$ & & & $\mathrm{x}$ \\
\hline
\end{tabular}




\begin{tabular}{|c|c|c|c|c|c|c|c|c|c|c|}
\hline \multirow[b]{2}{*}{ Citation } & \multirow[b]{2}{*}{ Annotation } & \multirow[b]{2}{*}{ ঠ্ঠু } & \multicolumn{8}{|c|}{ Topics addressed } \\
\hline & & & 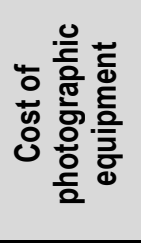 & 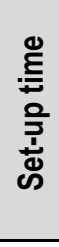 & 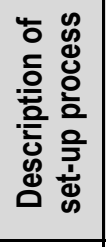 & 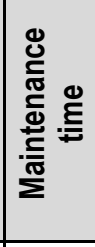 & 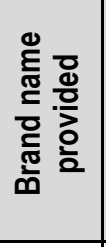 & 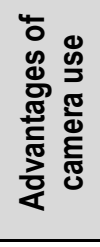 & 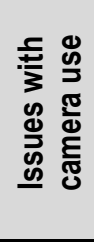 & 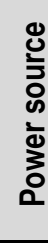 \\
\hline $\begin{array}{l}\text { York, E.C., Moruzzi, T.L., } \\
\text { Fuller, T.K., Organ, J.F., } \\
\text { Sauvajot, R.M., and } \\
\text { DeGraaf, R.M., 2001, } \\
\text { Description and evaluation } \\
\text { of a remote camera and } \\
\text { triggering system to } \\
\text { monitor carnivores: } \\
\text { Wildlife Society Bulletin, } \\
\text { v. } 29, \text { no. } 4, \text { p. } 1228-1237 .\end{array}$ & $\begin{array}{l}\text { In this study, an automatic camera was used to photograph } \\
\text { animals of sufficient size to trigger a pressure plate. The } \\
\text { authors provide a detailed description of how to wire a } \\
\text { camera to a pressure trigger plate and how to assemble a } \\
\text { weatherproof camera-housing unit. }\end{array}$ & 2001 & $\mathrm{x}$ & & $\mathrm{x}$ & & $\mathrm{x}$ & & $\mathrm{x}$ & \\
\hline $\begin{array}{l}\text { Kleist, A.M., Lancia, R.A., } \\
\text { and Doerr, P.D., 2007, } \\
\text { Using video surveillance to } \\
\text { estimate wildlife use of a } \\
\text { highway underpass: } \\
\text { Journal of Wildlife } \\
\text { Management, v. } 71 \text {, no. } 8 \text {, } \\
\text { p. } 2792-2800 .\end{array}$ & $\begin{array}{l}\text { The description of the camera system used in this study is } \\
\text { brief. A digital camera was connected to a digital video } \\
\text { recorder. The authors describe the advantages of switching } \\
\text { to solar power for the cameras (not just a solar recharge for } \\
\text { batteries) from using batteries. The solar power provided } \\
\text { sufficient power to record with minimal interruptions; the } \\
\text { batteries provided sufficient power for } 4-7 \text { days of } \\
\text { recording. }\end{array}$ & 2007 & & & & $\mathrm{x}$ & $\mathrm{x}$ & & & $\mathrm{x}$ \\
\hline $\begin{array}{l}\text { Hebert, P.N., and } \\
\text { Golightly, R.T., 2007, } \\
\text { Observations of predation } \\
\text { by corvids at a Marbled } \\
\text { Murrelet nest: Journal of } \\
\text { Field Ornithology, v. } 78, \\
\text { no. 2, p. 221-224. }\end{array}$ & $\begin{array}{l}\text { The authors do not describe the camera system they used in } \\
\text { much detail but this article includes a more recent data } \\
\text { collection period (2002-2005) and the equipment may be } \\
\text { more current than the equipment described in some other } \\
\text { articles. The authors used a video camera connected by } \\
\text { cable to a time-lapse VCR located near the study nest. }\end{array}$ & 2007 & & & & $\mathrm{x}$ & $\mathrm{x}$ & & & $\mathrm{x}$ \\
\hline $\begin{array}{l}\text { George, S.L., and Crooks, } \\
\text { K.R., 2006, Recreation and } \\
\text { large mammal activity in } \\
\text { an urban nature reserve: } \\
\text { Biological Conservation, v. } \\
\text { 133, no. 1, p. } 107-117 .\end{array}$ & $\begin{array}{l}\text { In this study, authors used cameras in areas considered high } \\
\text { risk and in areas considered low risk for theft. The cameras } \\
\text { took still photography. The authors describe the different } \\
\text { approaches used to secure their infrared cameras in these } \\
\text { two types of areas. }\end{array}$ & 2006 & & & $\mathrm{x}$ & $\mathrm{x}$ & $\mathrm{x}$ & & & \\
\hline
\end{tabular}




\begin{tabular}{|c|c|c|c|c|c|c|c|c|c|c|}
\hline & & & \multicolumn{8}{|c|}{ Topics addressed } \\
\hline Citation & Annotation & ঠ্ঠ & 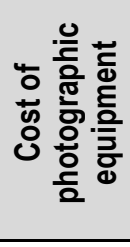 & 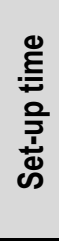 & 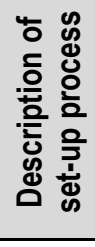 & 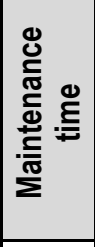 & 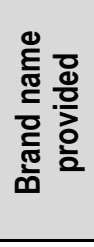 & 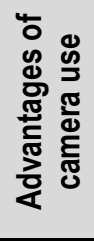 & 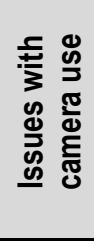 & 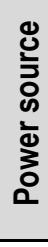 \\
\hline $\begin{array}{l}\text { Locke, S.L., Cline, M.D., } \\
\text { Wetzel, D.L., Pittman, } \\
\text { M.T., Brewer, C.E., and } \\
\text { Harveson, L.A., 2005, A } \\
\text { web-based digital camera } \\
\text { for monitoring remote } \\
\text { wildlife: Wildlife Society } \\
\text { Bulletin, v. 33, no. 2, p. } \\
761-765 .\end{array}$ & $\begin{array}{l}\text { In this article, the authors describe using photographic } \\
\text { technology to collect data in a remote location. They used a } \\
\text { web-based digital camera, activated by motion and heat } \\
\text { detection, to photograph wildlife in an area that was not } \\
\text { easily accessible. A unique aspect of the study described in } \\
\text { this article is how the authors were able to retrieve the } \\
\text { photographs remotely. They set up a laptop and satellite } \\
\text { phone in the field with the camera. The laptop was } \\
\text { programmed to turn the satellite phone on twice daily and } \\
\text { send the photographs to a server. The camera and laptop } \\
\text { were battery powered with solar recharge capability. The } \\
\text { authors also describe how they made the photos available to } \\
\text { the public online; however, they did not conduct any } \\
\text { assessment of viewing or use of photos by the public. }\end{array}$ & 2005 & $\mathrm{x}$ & & & & $\mathrm{x}$ & & & $\mathrm{x}$ \\
\hline $\begin{array}{l}\text { Grassman, L.I., Jr., Tewes, } \\
\text { M.E., and Silvy, N.J., } \\
\text { 2005, Armoring the } \\
\text { Camtrakker@ camera-trap } \\
\text { in a tropical Asian forest: } \\
\text { Wildlife Society Bulletin, } \\
\text { v. } 33 \text {, no. 1, p. 349-352. }\end{array}$ & $\begin{array}{l}\text { The authors of this article focused on the development of a } \\
\text { protective casing for cameras used for remote photography. } \\
\text { They developed a steel shell casing for the camera } \\
\text { equipment and a mounting bracket suitable to attach the } \\
\text { casing to a tree and they describe in detail the procedure to } \\
\text { assemble the casing and bracket. They tested the casing in } \\
\text { an area populated by elephants; the protective casing } \\
\text { proved to be useful in deterring elephant damage. The } \\
\text { authors believe this type of casing may also be useful in } \\
\text { locations with large carnivores or where there is a threat of } \\
\text { theft. }\end{array}$ & 2005 & $\mathrm{X}$ & & $\mathrm{x}$ & & $\mathrm{X}$ & & & \\
\hline
\end{tabular}




\begin{tabular}{|c|c|c|c|c|c|c|c|c|c|c|}
\hline & & & \multicolumn{8}{|c|}{ Topics addressed } \\
\hline Citation & Annotation & 离 & 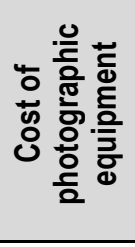 & 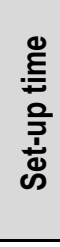 & 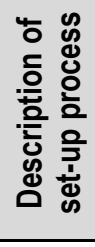 & 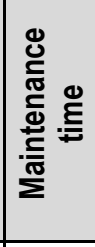 & 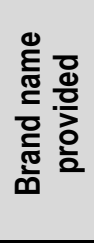 & 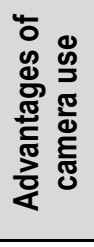 & 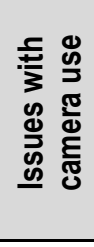 & 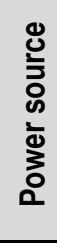 \\
\hline $\begin{array}{l}\text { Cutler, T.L., and Swann, } \\
\text { D.E., 1999, Using remote } \\
\text { photography in wildlife } \\
\text { ecology-A review: } \\
\text { Wildlife Society Bulletin, } \\
\text { v. } 27 \text {, no. } 3 \text {, p. } 571-581 \text {. }\end{array}$ & $\begin{array}{l}\text { The authors discuss and review use of remote photography } \\
\text { in wildlife studies. This article doesn't include a discussion } \\
\text { of webcams because that technology was not popular at the } \\
\text { time the article was written. However, the authors describe } \\
\text { the advantages and disadvantages of remote photography } \\
\text { for different types of studies (for example, studies of } \\
\text { nesting behavior, studies to detect presence of species). } \\
\text { They describe conditions under which time-lapse versus } \\
\text { animal-triggered systems are most appropriate. These } \\
\text { issues are important to consider for those using any type of } \\
\text { remote photography, including webcams. }\end{array}$ & 1999 & $\mathrm{x}$ & & & & & $\mathrm{x}$ & $\mathrm{x}$ & \\
\hline $\begin{array}{l}\text { Watts, D.E., Parker, I.D., } \\
\text { Lopez, R.R., Silvy, N.J., } \\
\text { and Davis, D.S., 2008, } \\
\text { Distribution and abundance } \\
\text { of endangered Florida Key } \\
\text { Deer on outer islands: } \\
\text { Journal of Wildlife } \\
\text { Management, v. } 72 \text {, no. } 2 \text {, } \\
\text { p. } 360-366 .\end{array}$ & $\begin{array}{l}\text { This study was conducted with digital, infrared-triggered } \\
\text { cameras to observe and survey a species (Key deer) that is } \\
\text { difficult to study with traditional methods. The researchers } \\
\text { used a camera programmed to take an initial still } \\
\text { photograph and then to record } 10-20 \text { seconds of video } \\
\text { immediately following. }\end{array}$ & 2008 & & & $\mathrm{x}$ & & $\mathrm{x}$ & & & \\
\hline
\end{tabular}




\begin{tabular}{|c|c|c|c|c|c|c|c|c|c|c|}
\hline & & & \multicolumn{8}{|c|}{ Topics addressed } \\
\hline Citation & Annotation & ষ্ঠ & 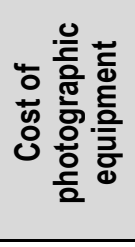 & 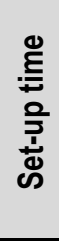 & 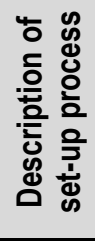 & 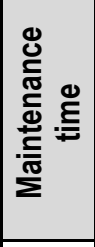 & 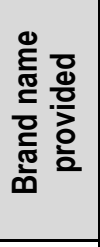 & 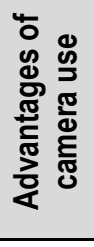 & 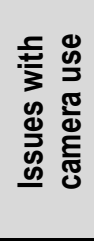 & 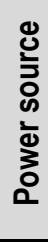 \\
\hline $\begin{array}{l}\text { Kelly, M.J., Noss, A.J., Di } \\
\text { Bitetti, M.S., Maffei, L., } \\
\text { Arispe, R.L., Paviolo, A., } \\
\text { De Angelo, C.D., and Di } \\
\text { Blanco, Y.E., 2008, } \\
\text { Estimating puma densities } \\
\text { from camera trapping } \\
\text { across three study sites-- } \\
\text { Bolivia, Argentina, and } \\
\text { Belize: Journal of } \\
\text { Mammalogy, v. 89, no. 2, } \\
\text { p. 408-418. }\end{array}$ & $\begin{array}{l}\text { The researchers used a camera to take still photos; they } \\
\text { mentioned a list of brand names of cameras they used but } \\
\text { did not describe any other specifications. They include an } \\
\text { appendix discussing issues of identifying individual pumas } \\
\text { in photos. }\end{array}$ & 2008 & & & $\mathrm{x}$ & & $\mathrm{x}$ & & & \\
\hline $\begin{array}{l}\text { Donaldson, B., 2007, Use } \\
\text { of highway underpasses by } \\
\text { large mammals and other } \\
\text { wildlife in Virginia- } \\
\text { Factors influencing their } \\
\text { effectiveness: } \\
\text { Transportation Research } \\
\text { Record, v. 2011, p. } 157- \\
164 \text {. }\end{array}$ & $\begin{array}{l}\text { The study described in this article involved mounting } \\
\text { digital cameras and highway underpasses to document use } \\
\text { of these pathways by wildlife. The author describes use of } \\
\text { two types of cameras, one of which was better suited to } \\
\text { sites where human visitation was expected, where the } \\
\text { cameras were mounted at the sites, and how frequently the } \\
\text { cameras were visited to download photographs and replace } \\
\text { batteries. }\end{array}$ & 2007 & & & & $\mathrm{x}$ & $\mathrm{x}$ & & & \\
\hline $\begin{array}{l}\text { Maniscalco, J.M., Parker, } \\
\text { P., and Atkinson, S., 2006, } \\
\text { Interseasonal and } \\
\text { interannual measures of } \\
\text { maternal care among } \\
\text { individual Steller sea lions } \\
\text { (Eumetopias jubatus): } \\
\text { Journal of Mammalogy, v. } \\
\text { 87, no. 2, p. 304-311. }\end{array}$ & $\begin{array}{l}\text { This study used remote-operated video cameras with } \\
\text { imagery sent via cable to a control tower; the control tower } \\
\text { in turn transmitted images via microwave transmissions. } \\
\text { Incoming data was recorded using video recorders at the } \\
\text { research center, not the study site. The equipment was } \\
\text { battery powered with wind and solar battery recharge. }\end{array}$ & 2006 & & & $\mathrm{x}$ & & & & & $\mathrm{x}$ \\
\hline
\end{tabular}




\begin{tabular}{|c|c|c|c|c|c|c|c|c|c|c|}
\hline \multirow[b]{2}{*}{ Citation } & \multirow[b]{2}{*}{ Annotation } & \multirow[b]{2}{*}{ 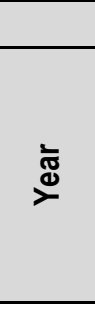 } & \multicolumn{8}{|c|}{ Topics addressed } \\
\hline & & & 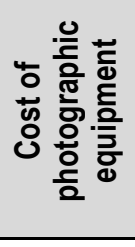 & 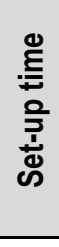 & 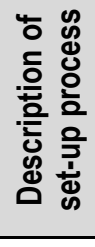 & 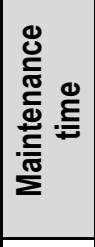 & 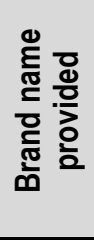 & 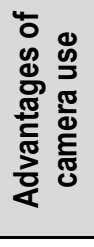 & 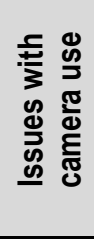 & 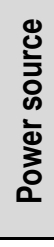 \\
\hline $\begin{array}{l}\text { Silveira, L., Jacomo, } \\
\text { A.T.A., and Diniz-Filho, } \\
\text { J.A.F., 2003, Camera trap, } \\
\text { line transect census and } \\
\text { track surveys-A } \\
\text { comparative evaluation: } \\
\text { Biological Conservation, v. } \\
\text { 114, no. 3, p. 351-355. }\end{array}$ & $\begin{array}{l}\text { In this article, the authors do not describe in much detail the } \\
\text { specific camera setup they used. Instead of describing the } \\
\text { specific setup they used, the authors focused on the } \\
\text { advantages of conducting camera-based surveys rather than } \\
\text { other methods of studying wildlife. The advantages they } \\
\text { describe include the ability to use camera technology to } \\
\text { observe nocturnal animals, accuracy of species } \\
\text { identification, low environmental disturbance, and ease of } \\
\text { use. }\end{array}$ & 2003 & & & & & $\mathrm{x}$ & $\mathrm{x}$ & & \\
\hline $\begin{array}{l}\text { Smith, K.L., Jr., } \\
\text { Kaufmann, R.S., and } \\
\text { Wakefield, W.W., 1993, } \\
\text { Mobile megafaunal activity } \\
\text { monitored with a time- } \\
\text { lapse camera in the abyssal } \\
\text { north Pacific: Deep Sea } \\
\text { Research Part I- } \\
\text { Oceanographic Research } \\
\text { Papers, v. 40, no. 11-12, p. } \\
\text { 2307-2324. }\end{array}$ & $\begin{array}{l}\text { Although this article is dated, the authors provide a } \\
\text { thorough description of the camera tripod they constructed } \\
\text { to photograph underwater. They used a camera with color } \\
\text { negative film. They describe the use of strobe lights to } \\
\text { provide adequate lighting for the photographs and the use } \\
\text { of ballast to stabilize the camera tripod. }\end{array}$ & 1993 & & & $\mathrm{x}$ & & & & & $\mathrm{X}$ \\
\hline $\begin{array}{l}\text { Hristov, N.I., Betke, M., } \\
\text { and Kunz, T.H., 2008, } \\
\text { Applications of thermal } \\
\text { infrared imaging for } \\
\text { research in aeroecology: } \\
\text { Integrative and } \\
\text { Comparative Biology, v. } \\
48, \text { no. } 1, \text { p. } 50-59 .\end{array}$ & $\begin{array}{l}\text { This article describes the use of thermal infrared imagery to } \\
\text { study free-ranging bats. The authors define and explain the } \\
\text { difference between cooled and uncooled thermal infrared } \\
\text { cameras. }\end{array}$ & 2008 & & & & & & $\mathrm{x}$ & & \\
\hline
\end{tabular}




\begin{tabular}{|c|c|c|c|c|c|c|c|c|c|c|}
\hline \multirow[b]{2}{*}{ Citation } & \multirow[b]{2}{*}{ Annotation } & \multirow[b]{2}{*}{ 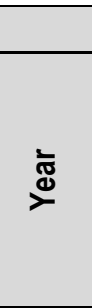 } & \multicolumn{8}{|c|}{ Topics addressed } \\
\hline & & & 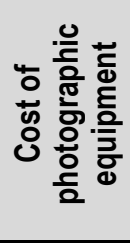 & 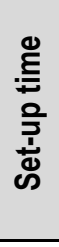 & 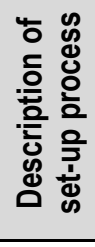 & 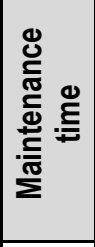 & 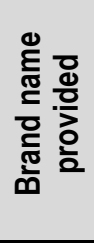 & 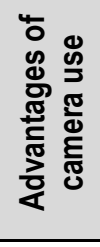 & 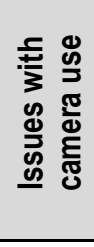 & 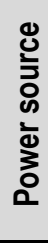 \\
\hline $\begin{array}{l}\text { Brough, M., and } \\
\text { Wigglesworth, S., 2005, A } \\
\text { journey in the future-- } \\
\text { Mossbrook School: Access } \\
\text { by Design, no. 104, p. } 17- \\
21 .\end{array}$ & $\begin{array}{l}\text { This article is not a research study but a case study in which } \\
\text { outdoor cameras transmit imagery into classrooms in a } \\
\text { school. The case study includes an innovative approach to } \\
\text { helping children understand pond life. A boat that can be } \\
\text { remote-controlled by the children has an underwater } \\
\text { camera mounted to the underside. The view from the } \\
\text { camera is broadcast into the classroom. }\end{array}$ & 2005 & & & $\mathrm{x}$ & & & & & \\
\hline $\begin{array}{l}\text { Cain, J.W., Morrison, } \\
\text { M.L., and Bombay, H.L., } \\
\text { 2003, Predator activity and } \\
\text { nest success of willow } \\
\text { flycatchers and yellow } \\
\text { warblers: Journal of } \\
\text { Wildlife Management, v. } \\
67, \text { no. } 3 \text {, p. } 600-610 .\end{array}$ & $\begin{array}{l}\text { The authors of this article do not describe the camera } \\
\text { system they used in much detail. The camera was electronic } \\
\text { and took still photographs. They do describe how they } \\
\text { connected the camera trigger to bait eggs placed in the nests } \\
\text { used in the study. }\end{array}$ & 2003 & & & $\mathrm{x}$ & & & & & \\
\hline $\begin{array}{l}\text { Langbein, J., Scheibe, } \\
\text { K.M., and Eichhorn, K., } \\
\text { 1998, Investigations on } \\
\text { periparturient behavior in } \\
\text { free-ranging mouflon sheep } \\
\text { (Ovis orientalis musimon): } \\
\text { Journal of Zoology, v. 244, } \\
\text { no. 4, p. 553-561. }\end{array}$ & $\begin{array}{l}\text { In this study of the behavior of wild sheep, the authors } \\
\text { needed to record both daytime and nighttime behavior. } \\
\text { They achieved this by using two video cameras: one a color } \\
\text { camera for daylight hours, the other an infrared camera } \\
\text { with infrared spotlights for nighttime recording. Imagery } \\
\text { was recorded on a time-lapse video recorder. }\end{array}$ & 1998 & & & & & $\mathrm{x}$ & & & \\
\hline
\end{tabular}


Publishing support provided by:

Denver Publishing Service Center

For more information concerning this publication, contact: Center Director, USGS Fort Collins Science Center

2150 Centre Ave., Bldg. C

Fort Collins, CO 80526-8118

(970)226-9398

Or visit the Fort Collins Science Center Web site at: http://www.fort.usgs.gov/ 